\title{
CRESCIMENTO DA POPULAÇÃO CATIVA EM UMA ECONOMIA AGROEXPORTADORA: JUIZ DE FORA (MINAS GERAIS), SÉCULO XIX*
}

\author{
Jonis Freire \\ Doutor em História pela Universidade Estadual de Campinas e \\ Professor do Programa de Pós-Graduação da Universidade Salgado de Oliveira
}

\begin{abstract}
Resumo
Este artigo aborda as possibilidades de manutenção e/ou ampliação da posse de cativos, seja por meio do tráfico ou da reprodução natural, em posses pertencentes a três grandes famílias proprietárias de cativos da Zona da Mata Mineira - Dias Tostes, Paula Lima e Barbosa Lage. Por meio do intercruzamento de fontes variadas concernentes àquelas famílias, conclui-se que as duas opções para o aumento do número de cativos - reprodução natural e tráfico de escravos - parecem não ter sido excludentes, mas sim complementares. A opção por uma ou outra dependeu, sobremaneira, do período de formação das posses, da maior ou menor proximidade com o tráfico transatlântico e também do raciocínio econômico empreendido pelos senhores na busca pelo melhor "modelo" para a manutenção e/ou ampliação de suas posses em escravos.

Pallavras-chave

tráfico de escravos • reprodução natural • Minas Gerais - século XIX
\end{abstract}

\section{Contato:}

R. Cabuçu, 76, ap. 402.

20710-300 - Rio de Janeiro - RJ

E-mail: jonisfreire@yahoo.com.br

* Pesquisa financiada pela Fundação de Amparo à Pesquisa do Estado de São Paulo. 


\title{
CAPTIVE POPULATION GROWTH IN AGRO-EXPORTING ECONOMY: MINAS GERAIS, IN THE NINETEENTH CENTURY
}

\author{
Jonis Freire
}

$\mathrm{PhD}$ in History for the Universidade Estadual de Campinas

\begin{abstract}
This article discusses the possibilities of maintenance and/or expansion of possession of captives, whether by means of trade or of natural reproduction in properties belonging to three families of captive owners of Zona da Mata Mineira - Dias Tostes, Paula Lima and Barbosa Lage. Through intercrossing of a variety of sources concerning those families, it is concluded that the two options for increasing the number of captives - natural reproduction and the slave trade - seem to have been not exclusive, but complementary. The choice of one or another has depended, above all, upon training period of the captives, the greater or lesser proximity to the transatlantic trade and also upon the economic reasoning undertaken by there in search for the best pattern for the maintenance and/or expansion of their slaves possessions.
\end{abstract}

Keywords

slave trade $\bullet$ natural reproduction $\bullet$ Minas Gerais - nineteenth century

\section{Contato:}

R. Cabuçu, 76, ap. 402.

20710-300 - Rio de Janeiro - RJ

E-mail: jonisfreire@yahoo.com.br 


\section{Hipóteses sobre o crescimento da população cativa no Brasil}

Questão importante com relação ao escravismo brasileiro é a relativa ao crescimento da sua população. Qual ou quais as formas encontradas pelos senhores de escravos para a manutenção e/ou a ampliação de suas posses? Nesse sentido, procuraremos compreender, neste artigo, como se deu o aumento da população cativa em três propriedades de Juiz de Fora no século XIX. Tal análise nos possibilita uma visão das estratégias utilizadas pelos proprietários no tocante à aquisição de suas escravarias.

Os debates historiográficos acerca do aumento da população cativa estão centrados basicamente em duas abordagens distintas. Uma das perspectivas analíticas sobre a manutenção/ampliação dos escravos é a que busca no tráfico (externo ou interno) a resposta para o aumento da mão de obra. ${ }^{1}$ Outra vertente sobre o crescimento da população é a da reprodução natural.

Segundo alguns estudiosos, o aumento do contingente escravo, por meio do nascimento, permitiria uma possível manutenção e/ou ampliação da mão de obra nas propriedades senhoriais. ${ }^{2}$ Este é um tema bastante discutido na historio-

\footnotetext{
Cf., entre outros, MOTTA, José Flávio; MARCONDES, Renato Leite. O comércio de escravos no vale do Paraíba paulista: Guaratinguetá e Silveiras na década de 1870. Estudos Econômicos. São Paulo, v. 30, n.2, 2000, p. 267-299; SLENES, Robert W. The Brazilian Internal Slave Trade, 1850-1888: Regional economies, slave experience and the politics of a peculiar market. In: JOHNSON, Walter (Org.). Domestic Passages: Internal Slave Trades in the Americas, 1808-1888. New Haven: Yale University Press, 2005; Idem. The demography and economics of brazilian slavery: 1850-1888. Tese de Doutoramento. Stanford University, 1976; KLEIN, Herbert S. A demografia do tráfico atlântico de escravos para o Brasil. Estudos Econômicos. São Paulo, v. 17, n. 2, maio/ago 1987, p. 129-149; FLORENTINO, Manolo. Em costas negras: uma história do tráfico de escravos entre a África e o Rio de Janeiro, século XVIII e XIX. São Paulo: Companhia das Letras, 1997; RODRIGUES, Jaime. O infame comércio: propostas e experiências no final do tráfico de africanos para o Brasil (1800-1850). Campinas: Editora da Unicamp/CECULT, 2000. MOTTA, José Flavio. Escravos daqui, dali e de mais além, o tráfico interno de cativos na expansão cafeeira paulista (Areias, Guaratinguetá, Constituição/Piracicaba e Casa Branca, 1861-1887). Tese de Livre Docência. Universidade de São Paulo, 2010.

2 PAIVA, Clotilde A.; LIBBY, Douglas C. Caminhos alternativos: escravidão e reprodução em Minas Gerais no século XIX. Estudos Econômicos. São Paulo, v. 25, n. 2, maio/ago 1995, p. 203-233; GUTIÉRREZ, Horacio. Demografia escrava numa economia não-exportadora: Paraná, 1800-1830. Estudos Econômicos, São Paulo, v. 17, n. 2, maio/ago 1987, p. 297-314; SANTOS, Jonas Rafael dos. Senhores e escravos: a estrutura da posse de escravos em Mogi das Cruzes no início do século XIX. Estudos de História, Franca, v. 9, n. 2, 2002, p. 235-253; BOTELHO, Tarcísio Rodrigues. Famílias e escravarias: demografia e família escrava no norte de Minas Gerais no século XIX. Dissertação de Mestrado, FFLCH-USP, 1994; BOTELHO, Tarcísio Rodrigues. Famílias e escravarias: demografia e família escrava no norte de Minas Gerais no século XIX. População e familia, São Paulo, v. 1, n. 1, jan./jun. 1988, p. 211-234; BERGAD, Laird W. Escravidão e história econômica: demografia de Minas Gerais, 1720-1888. Bauru: EDUSC, 2004. Algumas críticas sobre o trabalho de Bergad, feitas por Libby, podem ser vistas
} 
grafia e sua análise torna-se fundamental. Se houve, por parte dos senhores, um incentivo aos nascimentos, isso talvez indique não uma minimização do peso da escravidão, mas sim a existência de possibilidades encontradas pelos cativos para satisfazerem seus anseios dentro das limitações impostas pelo sistema escravista.

O Brasil é notadamente reconhecido como tendo sido o locus para onde foi levado o maior contingente dos escravos transportados do continente africano. A historiografia sobre esse tema, desde muito tempo, se debruça, dentre outros aspectos, sobre as possibilidades encontradas pelos proprietários brasileiros no que diz respeito à aquisição de sua mão de obra escrava, as rotas e o volume do tráfico. ${ }^{3}$

Parece-nos inquestionável a afirmação de que os proprietários brasileiros se utilizaram, durante vários anos, do tráfico intercontinental, com o intuito de adquirir mão de obra farta e relativamente barata. As estimativas sobre a quantidade de africanos trazidos para o Brasil são muitas. Eduardo França Paiva, por exemplo, baseando-se em diversos autores, aponta a percentagem de $38 \%$ deles em direção ao Brasil, entre os séculos XVI e XIX. O tráfico intercontinental foi, sem dúvida, um dos pilares do sistema escravista brasileiro. Tendo perdurado até o ano de 1850, foi por meio dele que se garantiu o abastecimento da Colônia e, depois, do Império, até pelo menos esse ano, constituindo-se o tráfico atlântico "em variável fundamental para a reprodução física da mão de obra cativa". ${ }^{4}$

David Eltis, em estudo sobre o tráfico transatlântico de escravos para as Américas, percebeu, primeiramente, que os portugueses foram os principais comerciantes a partir da África. Entre aqueles com nacionalidades conhecidas e que se aventuraram nesse tipo de comércio, foram eles os responsáveis pela aquisição dos maiores volumes de mão de obra escrava. De acordo com os seus cálculos, entre os anos de 1519 e 1867, 5.074 .900 africanos fizeram parte do comércio transatlântico, tendo os portugueses à frente dos negócios. Isso correspondeu a $45,9 \%$ do total de indivíduos comercializados entre aqueles anos. Em segundo lugar, vinham os Ingleses, com $28,1 \%$, e os Franceses, com 13,2\%. Segundo

em uma resenha no American Historical Review, v. 107, n. 1, 2002, p. 258-9. E também em LIBBY, Douglas Cole. Minas na mira dos Brasilianistas: reflexões sobre os trabalhos de Higgins e Bergad. In: BOTELHO, Tarcísio Rodrigues (Org.). História Quantitativa e Serial: um balanço. Belo Horizonte: ANPUH-MG, 2001; NOGUERÓL, Luiz Paulo Ferreira de. Economia escravista e preços de escravos em Minas Gerais: o caso de Sabará entre 1850 e 1887. Dissertação de Mestrado, UFMG/CEDEPLAR, 1997; TEIXEIRA, Heloisa Maria. Reprodução e famílias escravas de Mariana (1850-1888). Dissertação de Mestrado, Universidade de São Paulo, 2001. MATTOS DE CASTRO, Hebe Maria. Ao sul da história. São Paulo: Brasiliense, 1987.

3 SLENES, Robert W. The demography and economics..., op. cit. 1976; KLEIN, Herbert S., op. cit.; FLORENTINO, Manolo, op. cit; ; RODRIGUES, Jaime, op. cit.

${ }^{4}$ FRAGOSO, João; FLORENTINO, Manolo. Apud FLORENTINO, Manolo, op. cit., p. 27. 
Eltis, durante esse mesmo período, a maior parte dos cativos despachados para as Américas era da região da África Centro-ocidental - portos de Malembo, Loango, Cabinda, Ambriz e Benguela - 44,2\% (4.887,500 escravos) -, seguidos pelos da Baía do Benin e da Baía de Biafra com, respectivamente, $18,4 \%(2.034,600)$ e $13,7 \%(1.517,900){ }^{5}$

Com relação ao volume de cativos chegados às diversas regiões das Américas, por meio do tráfico transatlântico, o Brasil se sobressaiu como o local para onde foram enviadas as maiores levas de africanos. Nesse aspecto, a região Sudeste se destacou. Conforme os dados de Eltis, o Nordeste brasileiro, juntamente com a Bahia e o Sudeste foram responsáveis por 40,6\% dos 9.599.000 africanos traficados para as Américas, entre os séculos XVI e XIX. O Sudeste do Brasil foi a região que recebeu a maior quantidade de cativos, tanto em números absolutos quanto relativos: foram 2.017 .900 , o que equivalia a $21,0 \%$ do total. Sobretudo, entre os anos de 1801-1850, ocorreram os maiores desembarques no Sudeste brasileiro, ou seja, $1.145 .100-56,7 \%$ dos desembarcados nesta região. Em anos precedentes (1519-1800), as cifras chegaram a 869.300 (43,1\%) e, em anos posteriores, o número caiu vertiginosamente, chegando, entre 1851-1867, a $0,2 \%$, o que correspondia a 3.600 africanos. $^{6}$

Minas Gerais é, segundo os pesquisadores, a maior possuidora de escravos no século XIX. Conforme estimativas de Eduardo França Paiva, desde o século XVIII, a Capitania contava com um alto número de cativos. Segundo sua análise em testamentos e inventários, para as Comarcas do Rio das Mortes e do Rio das Velhas, eram cerca de $2 / 3$ de africanos e $1 / 3$ de crioulos, sendo que estes últimos possuíam uma composição sexual mais equilibrada àquela época, com uma supremacia masculina. Com relação às procedências dos que foram trazidos para Minas Gerais, o autor indicou que a maioria deles era oriunda da Costa da Mina e de Angola. ${ }^{7}$

Vários são os debates travados com a intenção de lançar luzes acerca dessa questão, tentando responder à seguinte pergunta: Como foi que a Província mineira conseguiu obter esse grande percentual? O diálogo gerado entre Roberto Martins e Robert Slenes sobre essa questão, bem como os trabalhos de Francisco

5 ELTIS, David. The volume and structure of the transatlantic slave trade: a reassessment. William and Mary Quaterly, 3d Series, Volume 58, Number I, January 2001, Tabelas I e II.

6 Idem, Ibidem, Tabela III.

7 PAIVA, Eduardo França. Escravidão e universo cultural na colônia: Minas Gerais, 1716-1789. Belo Horizonte: UFMG, 2001, p. 118. 
Vidal Luna e Wilson Cano, são interessantes e ainda norteiam as discussões sobre o crescimento da população cativa mineira. ${ }^{8}$

Até o final da década de 1970, havia um consenso, entre os historiadores, de que a economia de Minas no Oitocentos foi caracterizada por uma estagnação secular, que teve início no terceiro quartel do século XVIII, quando a produção aurífera declinou vertiginosamente. Segundo essa visão "convencional", o fator econômico primordial da Capitania deixou de existir, e a região passou por uma prolongada fase de involução, que resultou em regressão para a economia, baseada numa agropecuária de subsistência. ${ }^{9}$

Na sequência desse raciocínio, também se pensava que o enorme contingente de escravos, que o ciclo do ouro havia legado às gerações seguintes, teria, gradualmente, diminuído, em função do desgaste natural. Esses cativos teriam servido, ainda, como uma importante fonte de mão de obra para a expansão da cafeicultura pelo Vale do Paraíba, por São Paulo e por uma reduzida área da própria Província de Minas. ${ }^{10}$

Mais recentemente, os trabalhos sobre a economia mineira do século XIX destacaram a importância da Zona da Mata, porque esta concentrava, até 1888, a maior parte do trabalho escravo e também a maior densidade demográfica da Província. Em alguns desses estudos, já começavam a surgir problemas para os que assinalavam a estrutura econômica homogênea da região.

Roberto Martins demonstrou que a maioria das propriedades com escravos, em Minas, se fundamentava numa agricultura de subsistência de baixo grau de mercantilização. ${ }^{11}$ A economia provincial, para ele, era formada, basicamente, por

\footnotetext{
8 CANO, Wilson; LUNA, Francisco Vidal. A reprodução natural de escravos em Minas Gerais (século XIX): uma hipótese. Cadernos IFCH-UNICAMP, v. 10, out 1983, p. 1-14; MARTINS, Roberto Borges. Minas Gerais, século XIX: tráfico e apego à escravidão numa economia não-exportadora. Estudos Econômicos, v. 13, n. 1, jan/abr 1983, p. 181-209; SLENES, Robert. Os múltiplos de porcos e diamantes: a economia escrava de Minas Gerais no século XIX. Estudos Econômicos, v. 18, n. 3, 1988.

9 FURTADO, Celso. Formação econômica do Brasil. São Paulo: Nacional, 1969, 7 a ed., p. 91-3.

${ }^{10}$ COSTA, Emilia Viotti da. Da senzala à Colônia. São Paulo: DIFEL, 1966, p. 42-6.

11 MARTINS, Roberto Borges. Growing in silence: the slave economic of nineteenth century Minas Gerais (Brazil). Tese de Doutorado, University Vanderbilt, 1980; Idem. Minas Gerais, século XIX: tráfico e apego à escravidão numa economia não-exportadora. Estudos Econômicos, v. 13, n. 1, jan/abr 1983, p. 181-209; conferir também MARTINS FILHO, Amílcar; MARTINS, Roberto Borges. Slavery in a non-export economy: nineteenth century Minas Gerais revisited. Hispanic American Historical Review, v. 63, n. 3, 1983, p. 537-68. MARTINS, R. B.; MARTINS, Maria do Carmo Salazar. RBEP, v. 58, jan 1984, p. 105-20. Para uma discussão bibliográfica sobre a relação entre atividades exportadoras e de subsistência, conferir LENHARO, Alcir. As tropas da moderação. São Paulo: Símbolo, 1979, p. 33-37; MARTINS, R. B. A economia escravista de Minas Gerais no século XIX. Belo Horizonte, 1980, p. 4-5. O “fator Wakefield” é tratado por
} 
unidades agrícolas diversificadas internamente - fazendas, sítios e roças - cuja produção se destinava ao autoconsumo e à venda em mercados locais. Martins negou que a cafeicultura pudesse ter funcionado como polo de atração de trabalhadores escravos. De fato, do fim ou, pelo menos, da decadência da atividade mineradora ao surgimento do café, na Província, como produto importante, tinham transcorrido algumas décadas. Por outro lado, Minas Gerais não fora uma grande exportadora de escravos, ao contrário, teria participado grandemente do tráfico internacional e, depois, sido um expressivo lugar de destino dos africanos do comércio interprovincial. Ainda segundo o autor, Minas "teria sido um considerável importador líquido de escravos, mesmo com uma população estável ou naturalmente crescente". ${ }^{12}$

Em síntese, Roberto Martins destacou que a maioria dos escravos se radicava numa agricultura de subsistência, que as unidades agrícolas eram diversificadas internamente e que o café não foi polo de atração para cativos. A abundância de terras apropriáveis significou que continuariam sendo eles os únicos recursos disponíveis para os agricultores da região, e para outros, que não quiseram ganhar a vida pelo próprio suor. Esses argumentos foram novamente ressaltados por Martins, em artigo, no qual concluiu que, entre os anos de 1800 e 1852, a Província mineira teria absorvido $19 \%$ do total de escravos oriundos do tráfico atlântico para o Brasil, importando cerca de 320 mil pessoas. ${ }^{13}$

Contrariamente, Robert Slenes, dialogando com os estudos de Martins feitos na década de oitenta, notou que o desligamento da economia escravista mineira de agroexportação não era tão completo como afirmava o autor. Isto porque, direta ou indiretamente, determinados setores dessa economia, considerados dinâmicos,

WINCH, Donald. Classical political economy and the colonies. Cambridge: Harvard University Press, 1965, p. 90-104; NEIBOER, H. J. Slavery as an industrial system. Nova York: Burt Franklin, 1971, p. 417-22.

${ }^{12}$ Para Roberto Martins, Minas apresentava taxas negativas de crescimento natural, desta forma, as importações seriam as únicas responsáveis pelo aumento da população escrava. O autor só detectou duas regiões que fugiam a esse aspecto, o Sul dos Estados Unidos e Barbados. Martins explica o apego de Minas à escravidão pela reformulação parcial do "fator Wakefield", segundo o qual a escravidão era implantada em regiões caracterizadas por abundância de terras cultiváveis e facilmente apropriáveis por qualquer homem livre, desde que fosse possível produzir mercadorias de valor relativamente alto no mercado internacional. Para o autor, Minas Gerais representou um caso em que o componente de produção para exportação não foi necessário à permanência de um regime escravista; o essencial foi a existência de recursos abundantes e a constante disponibilidade de terras. MARTINS, Roberto Borges. Minas Gerais, século XIX..., op. cit., p. 187.

${ }^{13}$ MARTINS, Roberto Borges. Minas e o tráfico de escravos no século XIX, outra vez. In: SZMRECSÁNYI, Tamás; LAPA, José Roberto do Amaral. História econômica da independência ao império. São Paulo: HUCITEC, 1996, p. 103. 
participavam do complexo, gerando, desse modo, divisas para a Província. Além disso, segundo Slenes, há um problema na exposição de Martins: determinar a origem da disponibilidade de capitais para custear as grandes importações de escravos por uma economia tão pouco mercantilizada. Como explicar que essa economia de subsistência gerou recursos para maciças importações de escravos, e que, a partir de 1850 , passaram a ter uma tendência sempre crescente nos seus preços $?^{14}$

Nesse debate, a própria diversidade econômica da Província de Minas obsta a generalizações. Se havia grandes extensões territoriais, onde predominava a pecuária de corte com baixa utilização de mão de obra escrava, havia também uma pequena porção do território mineiro em que se praticava a cafeicultura nos padrões clássicos.

A incômoda combinação de um baixo grau de mercantilização e pesadas importações de cativos também preocupou Francisco Vidal Luna e Wilson Cano, para quem, no baixo grau de mercantilização, reside a explicação do imenso número de escravos. De acordo com os autores a violenta diminuição da taxa de exploração e o relaxamento dos costumes (mestiçagem e casamentos) permitiram o crescimento demográfico. ${ }^{15}$

Sobre esses problemas, Douglas Libby ofereceu outras explicações. Em primeiro lugar, defendeu que as atividades de transformação nos "setores dinâmicos" liberaram a Província de certas importações custosas, permitindo um ganho adicional. Concordando com Luna e Cano, quanto às causas das taxas positivas de crescimento da população mancípia, Libby acrescentou que o apego à escravidão se deveu a um complexo histórico, que foi a transformação de um determinado regime escravista regional. A diversificação da economia mineira e a importância do setor da agricultura de subsistência, mercantilizada ou não, bem como o desenvolvimento de uma protoindústria constituíram não uma mera resposta à independência econômica do campesinato, como quer Martins, e sim uma reação secular, específica da organização econômica e social escravista de Minas, à crise que lhe tirou a razão de ser original. A esse processo Libby chama "economia de acomodação". ${ }^{16}$

\footnotetext{
${ }^{14}$ SLENES, Robert. Os múltiplos de porcos e diamantes..., op. cit.

${ }^{15}$ LUNA, Francisco Vidal; CANO, Wilson. Economia escravista em Minas Gerais. Cadernos IFCH/ UNICAMP, v. 10, out 1983, p. 1-14

${ }^{16}$ LIBBY assinala a anterioridade desta posição em Celso Furtado. LIBBY, Douglas Cole. Transformação e trabalho em uma economia escravista: Minas Gerais no século XIX. São Paulo: Brasiliense, 1988. O autor tem também em conta a crítica do censo de 1872, feita por PAIVA, Clotilde Andrade; MARTINS, Maria do Carmo Salazar. Revisão crítica do recenseamento de 1872. Anais do Segundo Seminário sobre Economia Mineira. Belo Horizonte: CEDEPLAR/ FACE/UFMG, 1983, p. 149-63.
} 
Jonis FREIRE. Crescimento da população cativa em uma economia agroexportadora.

Ainda a esse respeito, Clotilde Paiva e Douglas Libby questionam a noção, para eles convencional, da dependência do tráfico negreiro internacional para manter ou aumentar as populações escravas. Segundo esses pesquisadores, o tráfico de escravos e a sua reprodução natural não são mutuamente excludentes. Analisando Minas Gerais, tanto antes como após o término do tráfico negreiro internacional, os autores argumentam que a orientação da economia mineira para o mercado interno favorecia o crescimento reprodutivo natural. Essa reprodução acontecia, mesmo levando-se em conta os efeitos adversos do comércio atlântico.

Paiva e Libby utilizam-se de Listas Nominativas e constatam que, na década de 1830, a população escrava de Minas Gerais se sustentava, em parte, por meio da reprodução natural, e, mais, que uma geração após o término do tráfico se encontrava plenamente reprodutiva.

O fluxo de escravos para Minas deve ter ficado bastante reduzido durante as últimas décadas do século XVIII e a primeira década do XIX. Se esta hipótese é correta, significaria que a população escrava experimentou um hiato de quase duas gerações durante o qual as influências 'negativas' do tráfico negreiro internacional ficaram bastante diminuídas. Neste caso, avanços em direção à reprodução natural deveriam ter ocorrido e teriam consequências importantes quando do novo aumento do volume de entradas de africanos. Uma grande e relativamente estável população crioula estaria se reproduzindo e, até um certo tempo, poderia ter absorvido uma parcela do novo contingente africano nos padrões de reprodução ou, ao menos, ter resistido à 'investida' dos recém-chegados. ${ }^{17}$

Luiz Paulo Nogueról, em estudo sobre a localidade mineira de Sabará, de 1850 a 1887, identificou que em uma região, com um mercado menos dinâmico, houve a possibilidade de obtenção de taxas de crescimento natural positivas, agregadas à importação de africanos. Embora se atenha ao caso de Sabará, aventou a possibilidade de que esse podia ser um fenômeno mineiro e não apenas sabarense. Em sua argumentação, para comprovar as estratégias de reprodução natural em Sabará, utiliza-se, sobretudo, de duas conclusões para reforçar tal hipótese, que residiam nos preços das escravas e dos recém-nascidos de ambos os sexos. Na primeira delas, alegou que, naquela localidade, após a Lei do Ventre Livre, houve uma queda nos preços das cativas, "o que atribuímos à eliminação dos ganhos com a procriação de escravos". ${ }^{18}$ A segunda se baseou nos preços dos recém-

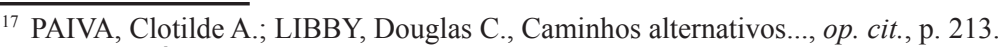

${ }^{18}$ NOGUERÓL, Luiz Paulo Ferreira de. Economia escravista..., op. cit., p. 101. O pesquisador se baseou na metodologia empregada por Fogel e Engerman em seus estudos sobre os preços de cativos no Sul dos Estados Unidos. "(...) optamos por verificar a hipótese de que os escravos recém- 
-nascidos, que se mostraram positivos entre os anos de 1850 e 1872, deixando de sê-lo a partir de 1873. "Isto porque a libertação aos 21 anos de idade dos filhos das escravas, a partir de 1872, impediria a amortização completa dos investimentos realizados em crianças". ${ }^{19}$ Em suma, o pesquisador defendeu a ideia de que

(...) predominavam em Minas Gerais regiões que, nos termos de Barros de Castro, eram residuais ou membros efetivos da cadeia, o que permite a coexistência de um mercado interno menos dinâmico com uma dependência demográfica menor com relação à reprodução local da força-de-trabalho. ${ }^{20}$

Horácio Gutiérrez, estudando a demografia escrava no Paraná, entre 1800 e 1830, sugeriu que o estudo de regiões não ligadas à economia de exportação permite vislumbrar dois movimentos demográficos na população escrava: o primeiro, típico das regiões de grande lavoura, o segundo mais próximo das regiões econômicas não exportadoras. Neste último a reprodução demográfica se daria sem que o recurso ao tráfico fosse decisivo, hipótese compartilhada por Jonas Rafael dos Santos, que, em seu estudo sobre Mogi das Cruzes (SP) no princípio do XIX, afirma existir uma associação entre reprodução natural e economia voltada para o mercado interno. ${ }^{21}$ Carlos Bacellar e Ana Silvia Scott concluíram que

A relação entre fatores econômicos e a escravidão fica patente ao surpreendermos a presença da criança no interior dos plantéis. Nas vilas de subsistência e abastecimento interno, as crianças, até 7 anos de idade, representavam de 18 a 20\% do total dos cativos, isto é, por volta de $1 / 5$ do grupo. Para a região canavieira, esta proporção cai para uma faixa entre 9 e $12 \% .{ }^{22}$

Tarcísio Botelho encontrou evidências do processo de reprodução natural entre os escravos, em Montes Claros, norte de Minas Gerais, ao longo do século XIX. Em uma economia baseada na pecuária e voltada para o mercado interno,

-nascidos em Minas Gerais obtinham preços relativos maiores do que zero, o que seria condição necessária, porém não suficiente, para que houvesse estímulos, ou se encontrasse desimpedida a procriação dos cativos. Se os preços desta classe de escravos não fossem significativamente diferentes de zero, então haveria razões econômicas para que os escravistas dificultassem ao máximo as gestações e uniões entre os escravos" (p. 1).

${ }^{19}$ Idem, Ibidem.

${ }^{20}$ Idem, Ibidem, p. 49.

${ }^{21}$ GUTIĖRREZ, Horácio. Demografia escrava..., op. cit.; SANTOS, Jonas Rafael dos. Senhores e escravos:..., op. cit.

${ }^{22}$ BACELLAR, Carlos de Almeida; SCOTT, Ana Silvia Volpi. Sobreviver na senzala: estudo da composição e continuidade das grandes escravarias paulistas, 1798-1818. In: NADALIN, Sérgio Odilon; et. alii (Coords.). História e população: estudos sobre a América Latina. São Paulo: Fundação Sistema Estadual de Análise de Dados, 1990, p. 214. 
desenvolveram-se, segundo ele, as possibilidades para a ocorrência de processos de reprodução natural. Em suma, o autor constatou que a localidade conseguiu preservar e mesmo expandir seu contingente cativo ao longo do Oitocentos. ${ }^{23}$ Botelho cita o seguinte:

A nosso ver, fica claro que, do ponto de vista senhorial, a reprodução natural é uma componente que entra positivamente em seus cálculos econômicos. Muitos a adotam como estratégia única de manutenção e ampliação do plantel. Outros, mesmo lançando mão do mercado, não desprezam sua importância. (...) parece significar também a manutenção da família escrava. Constantemente preservada, vemos casos de gerações que se sucedem dentro de um mesmo plantel, trazendo à vida dos cativos nela integrados um grande fator de estabilidade. ${ }^{24}$

Na Província de São Paulo, Herbert Klein e Francisco Vidal Luna, em trabalho sobre a sociedade e a economia escravista daquela região entre os anos de 1750 e 1850, atentaram para a importância do café como "mola" impulsionadora do crescimento da população escrava. Para atender à demanda cada vez maior por mão de obra, a solução foi o tráfico de escravos, vindos da África, e que se tornaram maioria. De acordo com os pesquisadores,

Em razão da idade e sexo desses imigrantes, a população cativa local não apresentava condições de se sustentar por crescimento natural. O crescimento da população escrava ocorria essencialmente por um grande afluxo de africanos. Estes constituíam entre $60 \%$ e $70 \%$ da força de trabalho cativa ocupada na cafeicultura. Mesmo nas atividades não-agrícolas, em fins da década de 1820, os africanos compunham metade da força de trabalho. ${ }^{25}$

Juliana Garavazo também apontou para a reprodução natural como possibilidade de aumento da população cativa de Batatais (SP), na segunda metade do Oitocentos. Verificou-se, naquela localidade, uma significativa participação de cativos menores de quinze anos, e, ainda, um menor desequilíbrio sexual na população escrava.

(...) notou-se uma tendência no sentido da maior proporção de escravos brasileiros à medida que se distanciava da data de proibição da entrada de escravos trazidos da África em território brasileiro (...), apesar dos africanos estarem presentes em pequeno número mesmo nas primeiras décadas subsequentes a tal medida (anos 1850 e 1860), atingindo, respectivamente, $24,2 \%$ e $31,0 \%$ do total. Neste caso, pode-se sugerir que os proprietá-

${ }^{23}$ BOTELHO, Tarcísio Rodrigues. Famílias e escravarias:..., op. cit.

${ }^{24}$ Idem, Ibidem, p. 232.

${ }^{25}$ LUNA, Francisco Vidal; KLEIN, Herbert S. Evolução da Sociedade e Economia Escravistas de São Paulo, de 1750 a 1850. São Paulo: EDUSP, 2005, p. 93. 
rios batataenses não recorreram sistematicamente ao mercado de escravos africanos para formação de seus plantéis enquanto este tipo de transação ainda era legal. ${ }^{26}$

Esse parece ter sido o panorama do tráfico até a primeira metade do século XIX. Na segunda metade, ele ganhou outras "feições". Houve a necessidade de obter mão de obra para as regiões onde havia um maior dinamismo econômico, principalmente as vinculadas a produtos que pudessem reverter lucros, utilizando-se do trabalho cativo, como por exemplo, o café. Dessa forma, os senhores de escravos e os traficantes passaram a utilizar, com mais vigor, os tráficos interprovinciais, intraprovinciais e/ou locais para a aquisição do produto, como foi o caso das Províncias do Rio de Janeiro, de São Paulo e Minas Gerais. ${ }^{27}$

Vale salientar que muito dessa proeminência se deveu a crises enfrentadas por outras Províncias do Império, o que possibilitou a transferência de cativos em direção às áreas deles necessitadas. ${ }^{28}$ A partir de então, os senhores tiveram de utilizar outros mecanismos, visando novas aquisições. Sem se desconsiderar o contrabando, ganhou mais dinamismo, sobretudo a partir da segunda metade do XIX, a opção pelo tráfico, fosse ele interprovincial, intraprovincial ou local. Sobre o período após 1850, Hebe Mattos esclareceu que, “(...) desde 1850, com a extinção do tráfico africano, a propriedade escrava - antes amplamente disseminada entre a população livre - passa a concentrar-se, por causa da alta do preço do cativo, nas mãos de grandes senhores das províncias cafeeiras". ${ }^{29}$

\footnotetext{
${ }^{26}$ GARAVAZO, Juliana. Riqueza e escravidão no Nordeste Paulista: Batatais, 1851-1887. Dissertação de Mestrado, História Econômica, FFLCH, USP, 2006, p. 155.

${ }^{27}$ Cf., entre outros, SLENES, Robert W. The demography and economics ..., op. cit.; COSTA, Emilia Viotti da. Da senzala à Colonia, op. cit. O tráfico interno já existia em período anterior, contudo, era reduzido, e contou primeiro com a mão de obra da população nativa. "Quando o tráfico africano terminou, uma sociedade complacente ajustou-se à nova realidade com um vasto e espontâneo aumento no movimento interno dos escravos, consequência da procura constante de mais escravos na região do café e de atitudes imutáveis no que se refere à própria instituição da escravatura". CONRAD, Robert. Os últimos anos da escravatura no Brasil 1850-1888. Rio de Janeiro: Civilização Brasileira, 1978, p. 64.

${ }^{28}$ CONRAD, Robert. Os últimos anos..., op. cit.

${ }^{29}$ MATTOS, Hebe Maria. Laços de família e direitos no final da escravidão. In: ALENCASTRO, Luiz Felipe de. História da Vida Privada no Brasil: Império. São Paulo: Companhia da Letras, $7^{\text {a }}$ reimpressão, 2004, p. 343. De acordo com Herbert Klein, Kátia Mattoso e Stanley Engermann: "O aumento brusco dos preços de escravos no Brasil não deve ser atribuído apenas ao fim do tráfico, mas também, e ainda mais importante, àquelas forças que aceleraram a demanda por mercadorias produzidas por escravos e com isso aceleraram a demanda por escravos. A expansão econômica europeia dos anos 50 em geral afetou os preços de escravos em todas as Américas". MATTOSO, Kátia Queiroz; KLEIN, Herbert; ENGERMAN, Stanley L. Notas sobre as tendências e padrões dos preços de alforria na Bahia, 1819-1888. In: REIS, João José (Org.). Escravidão e invenção da liberdade. Estudos sobre o negro no Brasil. São Paulo: Brasiliense, 1988, p. 68.
} 
Com relação à Província mineira, é interessante notar o alerta de Tarcísio Botelho: “(...) é necessário perceber melhor as possíveis diferenças entre as várias regiões mineiras, de modo a relativizar o peso seja do tráfico seja da reprodução natural na recomposição e/ou expansão das escravarias". ${ }^{30}$

No caso da Província do Rio de Janeiro, Ricardo Salles, baseando-se principalmente no Relatório do Presidente dessa Província, de 1851, chegou à hipótese de que houve

(...) dois processos distintos, ainda que interligados, na dinâmica demográfica da população escrava, uma africana e outra crioula. A primeira, predominante e determinante, a segunda, subordinada. Uma encobrindo a outra. A africana, masculina, adulta, com maior proporção de homens, dependente da alimentação do tráfico para sua reprodução. A crioula, mais equilibrada do ponto de vista sexual e etário, a longo prazo apresentando condições potenciais de reprodução natural positiva. ${ }^{31}$

O município de Juiz de Fora, objeto de estudo neste artigo, foi detentor do maior contingente de cativos no correr do século XIX na Província de Minas Gerais, e essa característica ajuda a tecer novas considerações em relação a esse debate. ${ }^{32} \mathrm{~A}$ análise das escravarias das três famílias senhoriais, encabeçadas por Antonio Dias Tostes, Comendador Francisco de Paula Lima e Capitão Manoel Ignácio de Barbosa Lage, que consideramos representativas no tocante aos grandes proprietários da Mata Mineira, nos possibilita detectar quais as estratégias adotadas por eles para a composição de suas escravarias. Permite também demonstrar quais as opções (tráfico e/ou reprodução natural) de que se valeram as ditas famílias para a manutenção e/ou a ampliação de suas posses.

Segundo Ângelo Alves Carrara, a Zona da Mata Mineira era, àquela época, uma área contígua ao Vale do Paraíba Fluminense, ${ }^{33}$ próxima ao porto do Rio de Janeiro, de onde eram escoadas as levas de escravos chegados do continente

${ }^{30}$ BOTELHO, Tarcísio Rodrigues. Famílias e escravarias:..., op. cit., p. 232.

${ }^{31}$ SALLES, Ricardo. Eo Vale era o escravo. Vassouras, século XIX. Senhores e escravos no coração do Império. Rio de Janeiro: Civilização Brasileira, 2008, p. 171.

${ }^{32}$ A esse respeito, entre outros, ver ANDRADE, Rômulo Garcia de. Limites impostos pela escravidão à comunidade escrava e seus vínculos de parentesco: Zona da Mata de Minas Gerais, século XIX. Tese de Doutorado, USP, 1995; GUIMARÃES, Elione Silva. Múltiplos viveres de afrodescendentes na escravidão e no pós-emancipação: família, trabalho, terra e conflito (Juiz de Fora-MG, 1828-1928). São Paulo; Juiz de Fora: Annablume; Funalfa Edições, 2006; LACERDA, Antonio Henrique Duarte. Os padrões de alforrias em um município cafeeiro em expansão: Juiz de Fora, Zona da Mata de Minas Gerais, 1844-1888. São Paulo: Fapeb; Annablume, 2006.

${ }^{33}$ CARRARA, Angelo Alves. A Zona da Mata de Minas Gerais: diversidade econômica e continuismo (1839-1909). Dissertação de Mestrado. História, Universidade Federal Fluminense, 1993. 
africano. A análise dessa região - não só por sua importância econômica e demográfica, mas também pela geográfica, que, sem dúvida, contribuiu para suprir as posses de escravos encontradas naquela área - permite perceber de que forma o tráfico influiu na composição das propriedades da localidade e - por que não dizer - da província mineira como um todo.

O tráfico de escravos está entre os motivos que explicam o grande contingente deles na província mineira durante o século XIX, oriundos, num primeiro momento, do continente africano e, depois, do tráfico nacional interno. Segundo França Paiva,

O tráfico africano abastecia todas as categorias, mas nas maiores, além dos cativos importados, houve uma grande quantidade de nascimentos. Isto aponta para uma prática comum de formação de famílias dentro das posses de cada senhor e para a reprodução natural da mão de obra como importante estratégia de renovação e ampliação dos contingentes de indivíduos mancípios. ${ }^{34}$

Claro está que as duas possibilidades, reprodução natural e tráfico, podem não ter sido excludentes, mas complementares, e é isto também que o artigo pretende averiguar.

\section{Reprodução natural e/ou tráfico de escravos?}

De acordo com os Livros de Registro de Batismo, que se encontram na Catedral e na Cúria Metropolitana de Juiz de Fora, o Capitão Antonio Dias Tostes ${ }^{35}$

\footnotetext{
${ }^{34}$ PAIVA, Eduardo França. Escravidão e universo cultural..., op. cit., p. 147.

${ }^{35}$ Antonio Dias Tostes, então com 55 anos de idade, era de longe o maior possuidor de cativos daquela localidade, de acordo com o recenseamento de 1831. A maioria esmagadora destes foi descrita como africano/africana e representava o maior número dos cativos existentes naquele fogo - 126. Em seguida vinham os descritos como crioulos, num total de 19, o recenseador incluiu nesse grupo dois escravos descritos como pardos. Esses números absolutos demonstram a grande supremacia de homens e mulheres africanos em relação aos crioulos e pardos. Nessa propriedade havia uma maioria de cativos do sexo masculino, tanto entre africanos quanto entre crioulos, $73,0 \%$ e $57,9 \%$, respectivamente. No entanto, é preciso ressaltar que os africanos eram quase três vezes mais do que suas parceiras de mesma origem. As cativas africanas $(27,0 \%)$, embora possuíssem um percentual menor do que as crioulas $(42,1 \%)$ eram em números absolutos mais representativas do que estas últimas. Esse fogo contava ainda com duas cativas designadas como pardas, que representavam a totalidade dos descritos como pardos. Na faixa de 1-14 anos, encontram-se 35 cativos, vinte e três escravos africanos, $65,7 \%$; oito crioulos, $28,6 \%$ e as duas pardas, $5,7 \%$. Na segunda faixa etária ( 15 - 40 anos), e a que abrigava o maior número dos cativos de Antonio Dias Tostes àquela época (105), estão inclusos 99 africanos, 94,3\%, e seis crioulos 5,7\%. Finalmente a última ( $41+$ anos), e a que contempla o menor número de cativos (07), possuía quatro africanos, $57,1 \%$ e três crioulos, $42,9 \%$. É nesta faixa etária onde se encontravam os libertos Antonia crioula e Ambrosio africano. Cf. FREIRE, Jonis. Escravidão e família escrava na Zona da Mata Mineira
} 
levou ao batismo, entre os anos de 1818 e 1832, 10 cativos nascidos em suas posses, sendo 6 meninos e 4 meninas. Não encontramos sua primeira esposa, Dona Anna Maria do Sacramento, fazendo o mesmo. Porém, sua segunda esposa, Dona Guilhermina Celestina da Natividade, levou 1 escravo e 5 escravas ao batismo, na década de 1850 .

O Capitão Tostes parece não se ter valido da reprodução natural de escravos para ampliar sua posse, já que, nas Listas de 1831, a maioria dos componentes do plantel era proveniente da África e estava na faixa acima dos quinze anos. Havia um número não desprezível de crianças $(1-14$ anos) que era, no ano do recenseamento, de 35 . O conhecimento de 10 nascimentos deixa antever que tal propriedade contou com muitas crianças cativas, naquela faixa etária (20 ao todo), oriundas do continente africano, quem sabe, trazidas para cá até com algum de seus pais. Essa hipótese reforça a percepção de que Antonio Dias Tostes procurava ampliar e manter sua posse por meio da compra de indivíduos provenientes do tráfico internacional, na primeira metade do século XIX.

Entre a Lista de 1831 e a partilha dos bens de D. Anna Maria do Sacramento, em $1837^{36}$, houve um acréscimo no número de crianças, o que fica perceptível com os 14 recém-nascidos (menores de 1 ano) de que pudemos ver o registro, embora não a tenhamos encontrado levando nenhum ao batismo. Entretanto, parece que ela continuou contando com a compra de escravos, provenientes do tráfico, já que sua força de trabalho entre os jovens/adultos aumentou. Mesmo se considerarmos que a faixa das crianças - que, em 1831, era de 35 cativos e, em 1837, de 30 - tenha contribuído para esse aumento, ainda assim houve crescimento,

oitocentista. Tese de Doutorado, História, Universidade Estadual de Campinas, 2009, p. 68. ${ }^{36}$ No ano de 1837 ocorreu a partilha dos bens da primeira esposa de Antonio Dias Tostes, Dona Anna Maria do Sacramento. Quanto à origem dos cativos, esta fonte demonstra que a grande maioria da escravaria dessa família continuava a ser composta por africanos, 108, os crioulos eram 33. Mesmo entre aqueles dos quais não foi possível conhecer a origem, os homens suplantam as mulheres, sendo 28 homens, $63,6 \%$ e 16 mulheres, $36,4 \%$. Os africanos que eram quase três vezes mais do que as africanas em 1831, já em 1837 eles haviam alcançado esta cifra. Os crioulos e crioulas que se equilibravam no ano do recenseamento, tinham agora uma supremacia dos homens, respectivamente, $66,7 \%$ e $33,3 \%$. Com relação a faixa etária, entre 1831 e 1837 , um aumento entre os cativos por nós considerados como jovens/adultos e uma diminuição nos denominados como crianças. Sem deixar de lado outras possíveis variáveis, para uma explicação a essas oscilações como a fuga, morte, venda de escravos, talvez isso possa ter acontecido pelo fato de essas crianças terem atingido os quinze anos de idade, levando-os a compor a faixa dos jovens. Os idosos permaneceram em mesmo número. Entretanto, se agregarmos às crianças os recém-nascidos, verificamos que aquela escravaria possivelmente contou no intervalo de tempo entre as duas fontes com um aumento de sua posse por meio do nascimento de cativos. Todavia, seria necessário o conhecimento das taxas de natalidade e mortalidade geral, para saber qual a taxa de aumento dessa população por meio da reprodução natural. Idem, Ibidem, p. 69. 
em virtude da compra de africanos. Do ponto de vista da lógica senhorial dessa família, parece claro que a mão de obra cativa se tornou maior por importação.

De acordo com os passaportes e os despachos emitidos na primeira metade do Oitocentos, pela Intendência de Polícia da Corte, Tostes levou para Minas Gerais 96 escravos. ${ }^{37}$ Em 24 de janeiro de 1829, comprou 22; no ano de 1830, foram outras três remessas, duas em janeiro e uma em abril, respectivamente, de 20, 20 e 34 , todos escravos novos, conforme consta das fontes. ${ }^{38}$ Sem dúvida, a família Tostes utilizou como estratégia de manutenção e/ou ampliação de suas posses o recurso do tráfico atlântico, por meio da compra na Corte, constituindo-se, conforme demonstrou Fabio W. Pinheiro, como uma das famílias da Mata Mineira que mais se utilizou desse tipo de reposição da mão de obra cativa. De acordo com Pinheiro:

Minas Gerais entre 1809 e 1830 foi o principal destino dos escravos, onde $40 \%$ das almas despachadas do Rio de Janeiro se dirigiram para este território, enquanto na província fluminense este índice foi de $36 \%$. Mais do que isso, verificamos também que dos escravos remetidos $97,8 \%$ eram africanos novos, se mostrando, assim, como um precioso indício da forte vinculação entre o tráfico Atlântico e a economia mineira. ${ }^{39}$

Outro daqueles grandes proprietários, o Comendador Francisco de Paula $\mathrm{Lima}^{40}$, levou ao sacramento do batismo, entre os anos de 1841 e 1862, 7 cativos. Nove anos se passaram e só mais tarde, precisamente em 1871, sua viúva levou 1 escravo para ser batizado. Os dados disponíveis mostram certo incremento da comunidade cativa, sobretudo enquanto o Comendador estava vivo. No entanto, entre a sua morte, em 1865, e a de sua viúva, em 1877, esse aumento, se ocorreu,

\footnotetext{
${ }^{37}$ Para um conhecimento a respeito dessa documentação, bem como das possibilidades e das "armadilhas" oriundas dessas fontes, conferir: FRAGOSO, João Luis; FERREIRA, Roberto Guedes Alegrias e Artimanhas de uma fonte seriada, despacho de escravos e passaportes da Intendência de Polícia da Corte, 1819-1833. Seminário de História Quantitativa e Serial no Brasil: um balanço. Ouro Preto: ANPUH-MG, 2001

${ }^{38}$ Respectivamente, Códice 421, v. 21, p. 255v; Códice 424, v. 04, p. 27; Códice 424, v. 04, p. 28 ; Códice 424, v. 04, p. 114. Arquivo Nacional (disponível no bando de dados do IPEA, em CD-ROM)

${ }^{39}$ PINHEIRO, Fabio Wilson Amaral. O tráfico atlântico de escravos na formação dos plantéis mineiros, Zona da Mata (c.1809 - c.1830). Dissertação de Mestrado, História, Universidade Federal do Rio de Janeiro, 2007, p. 148-149.

${ }^{40}$ O Comendador Francisco de Paula Lima, patriarca da família Paula Lima, falecido no dia 26 de novembro de 1865 , possuiu uma propriedade majoritariamente masculina, onde os homens somavam $68,1 \%$ da posse e as mulheres $31,4 \%$. Para um indivíduo, $0,5 \%$, não foi possível conhecer o sexo. Nesta posse também houve uma maior concentração de cativos entre os jovens/adultos (15-40 anos), com 136 escravos. Logo depois, vinham os 35 idosos, seguidos por 29 crianças e apenas 01 recém-nascido. Os escravos descritos como crioulos eram 19, dois deles procedentes da Bahia. FREIRE, Jonis. Escravidão e família..., op. cit., p. 76.
} 
foi por meio de outras estratégias de manutenção e/ou ampliação de suas posses de cativos, já que, D. Francisca Benedicta de Miranda Lima levou apenas 1 escravo ao batismo. ${ }^{41}$ Talvez a explicação para tal hiato tenha ocorrido por dois motivos que, diga-se de passagem, podem não ser excludentes. Primeiro, pode ter havido nascimento de crianças no interior daquela propriedade, não tendo havido tempo de tais batismos serem lavrados nos Livros de Registro, devido à morte precoce daqueles infantes. Pode também ter acontecido outro evento, qual seja, o batismo de crianças cativas pertencentes aos herdeiros, depois da partilha dos bens do Comendador, e, a partir de então, o pároco anotava como sendo eles os proprietários de tais inocentes. Outra hipótese diz respeito aos ingênuos nascidos pós-1871, que, segundo a Lei do Ventre Livre, eram livres e, portanto, não teriam sido batizados como pertencentes àqueles indivíduos.

\footnotetext{
${ }^{41}$ No ano de 1877, aos 27 dias do mês de outubro, faleceu a viúva do Comendador Francisco de Paula Lima, Dona Francisca Benedicta de Miranda Lima. De acordo com o inventário da mesma, esta senhora possuía à época 130 cativos, o documento listou ainda, nove ingênuos. Passados onze anos, desde o inventário do Comendador, percebemos um decréscimo no número de escravos, o que não é de se espantar se consideramos que neste intervalo de tempo houve a partilha dos bens daquele senhor, inclusive os escravos, no ano de 1866. Logicamente podem ter existido outros fatores que levaram a essa baixa no número de cativos, como vendas, óbitos e dívidas. Ainda podemos encontrar mais homens do que mulheres escravas, todavia, apesar da diferença, os números tendem mais a se equilibrar. Houve uma diminuição no número total de homens com relação às mulheres. Enquanto estes diminuíram, mais ou menos em torno de $10 \%$, estas aumentaram na mesma proporção. As alterações das percentagens nas três faixas etárias se deveram, dentre outros motivos, pela própria variação de tempo, ou seja, houve ali uma mudança dos cativos em suas faixas de idade. Muitos dos cativos que conseguiram sobreviver e estavam, por exemplo, na faixa dos recém-nascidos em 1866, com o passar dos anos passaram a integrar a faixa das crianças, enquanto que os desta faixa eram em 1877 jovens/adultos, e assim sucessivamente. Tanto no inventário do Comendador Francisco de Paula Lima, quanto no de sua esposa, D. Francisca Benedicta de Miranda Lima, um pequeno percentual de africanos com procedência conhecida. Parece que a posse de escravos envelheceu, entretanto, este envelhecimento deve ser matizado, pois as crianças nascidas após a Lei do Ventre Livre de 1871, nove ingênuos, que a partir de então eram livres, não foram computadas. A análise das duas Tabelas parece corroborar essa "passagem" entre as faixas. Em 1866 eram 32 crianças e um recém-nascido, 16,1\% do total de escravos, já em 1877 esse número caiu para nove, $7 \%$. Isso fica ainda mais perceptível nas faixas dos jovens/adultos e na dos idosos. Enquanto a primeira possuía 136 cativos, 66,6\%, passou a contar em 1877, com 57 escravos, 43,9\%; a segunda teve sua percentagem aumentada, de 35 idosos 17,7\%, abarcou em 1877,59 cativos, $45,4 \%$, passando a contar com a maior percentagem do total de cativos neste ano. No período em que a mão de obra escrava sofreu um aumento no preço dos cativos, sobretudo pelo fim do tráfico internacional, seria inviável, pelo menos do ponto de vista econômico, que depois da morte do Comendador, sua esposa ou herdeiros tivessem investido seus capitais em cativos com idades acima dos quarenta anos. Esta mudança pode demonstrar uma manutenção da comunidade escrava. Muitos dos cativos que habitaram a posse do Comendador durante seu ciclo de vida, inclusive suas famílias, devem ter continuado nesta propriedade até o momento da morte de D. Francisca Benedicta de Miranda Lima, ou quem sabe até mais. Idem, Ibidem, p. 77-78.
} 
Situação completamente diferente ocorreu com a propriedade do Capitão Manoel Ignácio Barbosa Lage. ${ }^{42}$ Entretanto, antes de entrarmos na análise de suas estratégias, é necessário que façamos algumas ressalvas a respeito desse senhor. Quando analisávamos os Livros de Registros Paroquiais de Batismo da Freguesia de Simão Pereira, deparamo-nos com o registro de vários cativos, cujo proprietário era Manoel Ignácio Barbosa ou, às vezes, Manoel Ignácio de Barbosa. Inicialmente, acreditamos que poderia ser um filho do Capitão Manoel Ignácio Barbosa Lage ou outro indivíduo qualquer, parente ou não dele. Entretanto, no decorrer do levantamento dos dados, mais e mais nos convencíamos de que era a mesma pessoa.

Isso ocorreu por vários motivos, primeiro, porque todas as grafias diziam respeito a um indivíduo residente na Freguesia de Simão Pereira, local de moradia do Capitão Manoel Ignácio Barbosa Lage, o que pode ser comprovado nos autos de seu inventário. Posteriormente, conseguimos encontrar Manoel Ignácio Barbosa, levando filhos à pia batismal com sua esposa, D. Florisbella Francisca de Assis Barbosa, foi esse o caso de seu filho Manoel Ignácio Barbosa Junior, batizado na Matriz de Nossa Senhora de Simão Pereira, filho legítimo do casal. A esposa tinha o mesmo nome da cônjuge do Capitão Manoel Ignácio de Barbosa Lage, inventariante de seu marido, chamada Dona Florisbella Francisca de Assis Barbosa Lage.

Ao que parece, o Capitão e sua esposa, em algum momento de sua história de vida, devem ter somado a seus nomes o sobrenome Lage, ou, quem sabe, esse sempre existiu e foi "esquecido" pelos responsáveis pela feitura dos assentos

\footnotetext{
${ }^{42}$ Outra das posses de escravos pesquisadas, qual seja a do Capitão Manoel Ignácio de Barbosa Lage, era composta, segundo seu inventário, em sua maioria por homens, $64,4 \%$, as mulheres constituíam 35,6\% de sua propriedade. Sobre a origem dos escravos pertencentes ao Capitão Manoel Ignácio Barbosa Lage, para um grande número não foi possível determinar esta variável. Para aqueles onde conseguimos averiguar esta informação observamos que os homens foram, em sua maioria, classificados como crioulos, num total de 31 indivíduos, que corresponde a $26,3 \%$. Os designados como africanos totalizavam 30 indivíduos, $25,4 \%$ do total da posse. As mulheres da mesma forma, em sua maior parte foram designadas como crioulas, 20 ou 16,9\%, as africanas eram 03 , e representavam $2,5 \%$ do total de 118 cativos. Os cativos para os quais esta informação não consta perfaziam 34 escravos $28,8 \%$. Dezoito anos após o fim efetivo do tráfico de escravos para o Brasil, a grande maioria dos cativos dessa posse, onde foi possível se saber a origem, era composta por escravos nascidos no Brasil $(43,2 \%)$. Quando averiguamos o sexo e a faixa etária onde se encontravam os cativos verificamos uma distribuição sempre maior dos homens em todas as faixas etárias, com exceção dos recém-nascidos que eram 03 meninos e 03 meninas. Na faixa das crianças havia 15 homens e 12 mulheres; na dos jovens/adultos, 37 homens e 21 mulheres; entre os adultos, respectivamente, 20 e 06 . Havia ainda 01 homem sem idade conhecida. Os africanos foram designados apenas como de nação, portanto, não pudemos traçar qual a procedência destes indivíduos. O conhecimento deste aspecto foi possível para apenas três cativos do sexo masculino dois deles designados como carioca e o outro como pernambucano, provavelmente oriundos do tráfico interprovincial. Idem, Ibidem, p. 80-81.
} 
paroquiais. Essa última hipótese parece-nos mais plausível, pois, voltando ao inventário desse senhor, temos a oportunidade de saber que era filho legítimo do Furriel Domingos Antonio Barbosa Lage e de Dona Rosa Maria de Jesus. Aliás, no ano de 1830, Manoel Ignácio Barbosa, juntamente com sua esposa Florisbella Barbosa, levou sua filha legítima, de nome Maria, ao batismo, e o padrinho foi registrado como Domingos Antonio Lage, provavelmente, o furriel, pai do Capitão Manoel, que também teve parte de seu nome "esquecido". Outra hipótese que pode ser levantada é a de que, na verdade, a ausência do sobrenome "Lage" nunca foi esquecida. Manoel Ignácio Barbosa, ou Barbosa Lage, era um senhor importante naquela localidade, que, futuramente, viria a obter a patente de capitão. Talvez pelo fato de ser tão conhecido e importante pudesse "prescindir" de seu sobrenome. Seu poderio econômico, político e financeiro deveria dispensá-lo, pelo menos naquela região, de seu nome e sobrenome.

Outra questão importante diz respeito ao desaparecimento do Capitão Manoel Ignácio de Barbosa Lage e das outras variações onomásticas descritas após o mês de março de 1868. Lembremo-nos de que o Capitão faleceu no dia 3 do dito mês e ano. A partir de então, encontramos escravos sendo batizados pelos herdeiros do Capitão e por sua viúva, D. Florisbella. Esses aspectos podem-se caracterizar como indícios fortes de que tais variações diziam respeito à mesma pessoa. Consideramos, então, que o Capitão Manoel Ignácio Barbosa Lage foi nomeado de três formas diferentes. Portanto, reputamos todas as variações como sendo representativas de um mesmo indivíduo.

Pois bem, se nosso raciocínio, baseado em tais evidências, está correto, o Capitão Manoel Ignácio Barbosa Lage levou ao sacramento do batismo um impressionante número de crianças escravas. De acordo com os registros paroquiais foram 62 inocentes, o que corresponderia a 52,5\% do total de 118, descritos em seu inventário, caso todos ainda se encontrassem vivos e naquela posse. Existiu, ainda, 1 escravo adulto que foi levado à pia batismal.

Embora houvesse um alto percentual de cativos com origem não descrita, acreditamos que deviam ser escravos nascidos no Brasil. O impacto da reprodução natural pode ser reforçado na análise da propriedade que possuía, entre os recém-nascidos e as crianças, um total de 33 escravos, todos eles crioulos, ou seja, mais da metade do número levado ao batismo. Havia 01 cativo do sexo masculino sem idade conhecida. Tratava-se de Andalixto crioulo, filho de Prudência e Antonio Pedreiro, ou seja, mais um nascido naquela propriedade. Não seria impossível pensar que o restante dessas crianças estivesse, agora, entre jovens/adultos 
daquela posse. Vale destacar que as três variações do nome do Capitão Manoel iam levando escravos ao sacramento do batismo entre os anos de 1818 e 1868.

A partir dessa última data, encontramos 3 inocentes recebendo aquele sacramento católico, entre 1868 e 1870, constando como pertencentes aos herdeiros do Capitão Manoel Ignácio de Barbosa Lage. Entre 1869 e 1878, foram 8 descritos como pertencentes à viúva, Dona Florisbella Francisca de Assis Barbosa Lage. Quatro desses nasceram depois da Lei do Ventre Livre.

Como já dissemos, é impressionante o número de cativos levados ao sacramento do batismo por essa família. Somando-se todos, temos 73 crianças sendo batizadas. Parece que os Barbosa Lage utilizaram, em suas posses, processos de reprodução natural, o que causou um enorme impacto na manutenção e/ou na ampliação delas.

Conseguimos conhecer os pais e/ou as mães de 37 daquelas crianças. Muitos deles possuíam filhos crioulos, que devem ter nascido dentro da propriedade. Dessa maneira, podemos encontrar Antonio pedreiro e Prudência com seus 6 filhos; Nicolao crioulo e Theodora, com 5 crianças; Matheos de Nação e Clemência, com 4; Racheo de Nação e Minelvina parda: cada uma com 3 filhos. Com 2 crianças descritas como seus filhos, encontramos ainda Catharina e Bartholomeo, Fidelis de Nação e Margarida [ininteligível?] de Nação e Roza, Silvério de Nação e Juliana, e Joaquina de Nação. Os outros cativos aparecem registrados juntos, cada um com apenas um rebento mencionado. Eram eles: Adão de Nação e Flora, Jerônimo crioulo e Lusia, Bernardino de Nação e Maximiana, Felippe carioca e Custódia, Heliodoro e Delphina, Lino de Nação e Constança. Se nossas hipóteses realmente estão corretas, parece que aquela posse contou com uma comunidade escrava bem enraizada e, quem sabe, baseada em relações de afetividade, amizade e solidariedade bastante fortes, com famílias preservadas, possibilitando àqueles indivíduos certa estabilidade.

A análise dos Livros de Notas e Escrituras Públicas permitiu averiguar como se deu a manutenção e/ou a ampliação dos cativos daquelas famílias, bem como qual ou quais os sentidos do tráfico, os setores da economia que demandavam aquela mão de obra, além de dados, como sexo, origem, idade, preço dos cativos, etc. Esse corpus documental foi de vital importância para o estudo do potencial escravista de uma determinada região e época.

Nesse aspecto, é interessante salientar que os Paula Lima foram os que mais se desfizeram de seus ativos em escravos. Os filhos do Comendador, ao que parece, não foram bons administradores de seus bens. Os encontramos levando muitos cativos à venda, inclusive, sob força de hipoteca e dívida. Nem o Comendador 
nem sua esposa venderam escravos, ao contrário, utilizaram o recurso da compra ou da cobrança de dívidas para o incremento de suas posses. Adquiriram, respectivamente, 17 e 13 cativos, em sua maioria homens.

O Capitão Manoel Ignácio obteve 5 escravos e não se desfez de nenhum. Talvez esse pequeno número, comprado por ele se justifique pelo fato de ter podido contar, em sua propriedade, com o crescimento natural de escravos. Surpreendente é a aquisição de grande número deles por parte de seu filho, Dr. Antero José Lage Barboza, que obteve um total de 97, sendo 60 homens, 35 mulheres e 2, cujo registro do sexo não encontramos.

Nos Livros de Notas e Escrituras Públicas ${ }^{43}$ que pesquisamos, entre os anos de 1857 e 1886, foram encontrados 627 cativos comercializados por aquelas três famílias senhoriais, por meio de compras e vendas, hipotecas, penhor, dívidas, doação e procuração ${ }^{44}$ (Tabela 1).

Tabela 1 - Sexo e faixa etária dos escravos que foram parte de algum tipo de transação comercial feita pelos Dias Tostes, pelos Paula Lima e pelos Barbosa Lage, em Juiz de Fora, 1857-1886

\begin{tabular}{|c|c|c|c|c|c|c|c|c|}
\hline $\begin{array}{c}\text { Faixa Sexo } \\
\text { etária }\end{array}$ & Masculino & $\mathbf{\%}$ & Feminino & $\mathbf{\%}$ & Não Consta & $\%$ & Total & $\%$ \\
\hline Recém-nascido & 01 & 0,2 & 01 & 0,4 & - & - & 02 & 0,3 \\
\hline $\mathbf{1 - 1 4}$ anos & 56 & 14,1 & 32 & 14,0 & - & - & 88 & 14,0 \\
\hline $\mathbf{1 5 - 4 0}$ anos & 237 & 59,9 & 139 & 60,4 & 01 & 100 & 377 & 60,1 \\
\hline $\mathbf{4 1 +}$ anos & 61 & 15,4 & 17 & 7,4 & - & - & 78 & 12,5 \\
\hline Não Consta & 41 & 10,4 & 41 & 17,8 & - & - & 82 & 13,1 \\
\hline Total & $\mathbf{3 9 6}$ & $\mathbf{1 0 0}$ & $\mathbf{2 3 0}$ & $\mathbf{1 0 0}$ & $\mathbf{0 1}$ & $\mathbf{1 0 0}$ & $\mathbf{6 2 7}$ & $\mathbf{1 0 0}$ \\
\hline
\end{tabular}

Fonte: Livros de Escritura Públicas, Compra e Venda de Escravos do Primeiro Ofício de Notas do AHCJF; Segundo Tabelionato de Notas de Juiz de Fora.

Esses cativos eram, em sua maioria, do sexo masculino (396). Existiram ainda 230 escravas. De 1 cativo não foi possível saber o sexo. Mais uma vez, nota-se a preferência pelos escravos do sexo masculino nas transações comerciais, ocorridas em Juiz de Fora. A soma dos cativos transacionados por aquelas

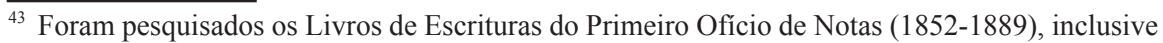
os dos distritos pertencentes àquele município e também os do Segundo Tabelionato de Notas de Juiz de Fora (1856-1888). Cabe ressaltar que esses livros só trazem informações a partir da segunda metade do século XIX. Todos se encontram sob a guarda do AHCJF.

${ }^{44}$ Essas são as transações comerciais mais comuns; cabe ressaltar que, na maioria das vezes, elas vêm descritas de maneiras diversas, como, por exemplo, Escritura de dívida obrigação e hipoteca especial, ou Escritura de doação como adiantamento de legítima, etc. 
famílias permite perceber que, de maneira geral, se continuava a dar preferência aos escravos entre 15-40 anos, fossem eles homens ou mulheres. Encontra-se também nessa faixa o cativo cujo sexo não foi possível conhecer. Seus valores percentuais foram, respectivamente, $59,9 \%$ e $60,4 \%$. Apesar de haver maior percentagem em relação aos homens, as mulheres negociadas naquele período foram 139, enquanto os escravos somavam 237. É interessante verificar que as mulheres com idades conhecidas tiveram, na faixa entre 1-14 anos, a segunda maior percentagem, $14,0 \%{ }^{45}$ Pode ser que, no momento dessas transações, os compradores tenham preferido adquirir essas "meninas" com potencial reprodutivo maior do que as que tinham acima de 41 anos. Da mesma forma, esse potencial reprodutivo, que elevava o preço da escrava, pode ter levado aqueles que delas se desfizeram, por venda, dívida, etc., a negociá-las mais do que as da faixa das idosas. Outra explicação residiria no fato de que essas mulheres, assim como os homens, trabalhavam no eito, o que pode ser comprovado por meio do conhecimento das ocupações desempenhadas por elas (Tabela 2).

\footnotetext{
${ }^{45}$ O decreto 1.695 de $15 / 09 / 1869$, em seu artigo $2^{\circ}$ determinava: "em todas as vendas de escravos, ou sejam particulares ou judiciais, é proibido, sob pena de nulidade, separar o marido da mulher, o filho do pai ou mãe, salvo sendo os filhos maiores de 15 anos" (Coleção das Leis do Império do Brasil). Algumas dessas "meninas" foram negociadas após essa data, o que talvez demonstre certa ineficácia da lei. Nos registros de compra e venda das mesmas não há menção a quaisquer tipos de relações familiares. Sobre essas questões: MOTTA, José Flavio. Jovens \& Coisas: transações envolvendo escravos de 9 a 17 anos de idade (Província de São Paulo, 1861-1887). In: SOARES, Marcio de Souza; FERREIRA, Roberto G.; FARIA, Sheila. S. C. I Colóquio Nacional Ordem e Ruptura em Debate: escravidão e alforria. UFF, 2011.
} 
Jonis FREIRE. Crescimento da população cativa em uma economia agroexportadora.

Tabela 2 - Ocupação dos escravos negociados pelos Dias Tostes, pelos Paula Lima e pelos Barbosa Lage, em Juiz de Fora, 1857-1886

\begin{tabular}{|c|c|c|c|c|c|c|}
\hline Ocupações & Homens & $\mathbf{\%}$ & Mulheres & $\mathbf{\%}$ & Total & $\mathbf{\%}$ \\
\hline Roceiro & 16 & 30,8 & 11 & 29,0 & 27 & 30,0 \\
\hline Serviço da lavoura & 17 & 32,7 & 06 & 15,7 & 23 & 25,6 \\
\hline Serviço da roça & 11 & 21,1 & 03 & 7,9 & 14 & 15,5 \\
\hline Serviço doméstico & - & - & 09 & 23,6 & 09 & 10,0 \\
\hline Alfaiate & 03 & 5,8 & - & - & 03 & 3,4 \\
\hline Cozinheira & - & - & 03 & 7,9 & 03 & 3,4 \\
\hline Copeiro & 02 & 3,8 & - & - & 02 & 2,2 \\
\hline Costureira & - & - & 02 & 5,3 & 02 & 2,2 \\
\hline Fiandeira & - & - & 02 & 5,3 & 02 & 2,2 \\
\hline Lavadeira & - & - & 02 & 5,3 & 02 & 2,2 \\
\hline Pedreiro & 02 & 3,8 & - & - & 02 & 2,2 \\
\hline Ferreiro & 01 & 2,0 & - & - & 01 & 1,1 \\
\hline Total & $\mathbf{5 2}$ & $\mathbf{1 0 0}$ & $\mathbf{3 8}$ & $\mathbf{1 0 0}$ & $\mathbf{9 0}$ & $\mathbf{1 0 0}$ \\
\hline
\end{tabular}

Fonte: Livros de Escritura Públicas, Compra e Venda de Escravos do Primeiro Ofício de Notas do AHCJF; Segundo Tabelionato de Notas de Juiz de Fora.

No que diz respeito às ocupações dos escravos negociados, para a maioria não havia essa informação. Seriam escravos sem "habilidade"? Talvez sim. Todavia, deviam, na verdade, ser cativos do "trabalho da roça/lavoura", que cultivavam o café e, portanto, não era necessário ter seu ofício descrito. Entretanto, para aqueles de que foi possível conhecer essa variável, a maioria foi descrita como "roceiro" e a "serviço da lavoura", seguida por aqueles designados como do "serviço da roça".

Embora a amostragem seja restrita, por essas designações podemos perceber que a localidade ainda estava vinculada às atividades agrícolas. Com certeza, ligadas ao seu produto principal de exportação - café - e, para tanto, visava à aquisição de mão de obra em idade produtiva e que pudesse ser utilizada na lavoura cafeeira. Essas três categorias de ocupação incluíam 64 indivíduos, 71,1\% de todos os escravos com ofício mencionado. A diferença entre roceiro e serviço de lavoura estava ligada à atividade produtiva desempenhada, que parecia estar associada a algum produto de exportação; melhor dizendo, a alguma atividade ligada à terra, que permitia altos lucros, como, por exemplo, o café. Já o ofício de roceiro vinculava-se às atividades mais relacionadas à lavoura de alimentos, 
já que se trata daquele "que faz e planta roçados, comumente de mandioca, e legumes; e difere do lavrador de canas, tabaco, algodão anil". ${ }^{46}$

De acordo com Rômulo Andrade, na segunda metade do século XIX houve, naquela localidade, que, segundo ele, se expandia tanto na área urbana quanto na rural, maior utilização de cativos, oriundos do tráfico interno, nos serviços do campo. Nessas transações,

Os cativos negociados eram, em sua maioria, jovens: 83 por cento tinha idade inferior a 35 anos. Portanto, o que se queria deles, era principalmente a plena capacidade produtiva. As ocupações que exerciam nem sempre eram determinantes na hora da efetivação dos negócios, pois 40 por cento dos registros sequer mencionam essa informação, talvez porque o direcionamento maior dessa mão de obra fosse a lavoura de café. De qualquer forma, o leque de atividades exercidas pelos cativos era múltiplo: lavradores/roceiros eram os mais frequentes, seguidos pelos empregados em serviços domésticos e cozinheiros. Os restantes se dividiam entre ofícios mais especializados, havendo, mesmo aqueles destinados a 'qualquer trabalho'. ${ }^{47}$

Outra ocupação genérica muito citada foi o "serviço doméstico", com 9 cativas. Se considerarmos que alfaiate, cozinheira, copeiro, costureira, fiandeira e lavadeira eram atividades ligadas ao serviço doméstico, esse tipo de trabalho aumenta bastante, atingindo um percentual de 25,6\%. Outros trabalhadores especializados, como pedreiro e ferreiro (3,3\%), também foram encontrados entre os cativos. É interessante notar a divisão entre as ocupações exercidas por homens e mulheres escravos. Com exceção das ligadas à roça ou à lavoura, que abrigavam ambos, as demais eram desempenhadas por um ou outro sexo, havendo destaque para as mulheres. Dezoito delas exerceram algum tipo de ocupação que não foi descrita para os homens. O inverso ocorreu com 8 homens.

Apenas 87 escravos, que foram alvo de trocas, vendas, dívidas, penhor, tiveram seu valor descrito. Os preços variaram entre os vinte e cinco mil réis $(25 \$ 000)$, como foi avaliado Pedro, crioulo de 2 meses de idade, vendido ao genro de Antonio Dias Tostes, o senhor Manoel Vidal Lage Barbosa. Dois contos e quinhentos mil réis (2:500\$000) foram pagos por Marcelino Dias Tostes a Francisco Araújo Lopes, morador no Pará, na Província de Minas Gerais, por cada um dos seguin-

\footnotetext{
${ }^{46}$ SILVA, Antonio de Moraes. Dicionário da Língua Portuguesa. 6. ed. Lisboa: Typ. de Antonio Jose da Rocha, 1858, p. 264 e 745.

47 ANDRADE, Rômulo Garcia de. Limites impostos..., op. cit., p. 90 . O autor ressaltou ainda a importância do aluguel de escravos, sobretudo pelas mulheres que exerciam tarefas relacionadas aos serviços domésticos (mucamas, cozinheiras, etc.), embora os cativos do serviço do eito também fossem alugados principalmente na época da colheita.
} 
tes cativos: Joaquim Nunes, preto, solteiro, de 40 anos, com ofício de pedreiro; Joaquim Bernardo, preto, também solteiro, de 32 anos de idade, descrito como roceiro, e por Manoel, preto, solteiro de 32 anos. Embora o número de cativos, com o valor descrito, seja pequeno, cabe tentar uma aproximação mesmo que superficial acerca dos preços praticados pelos envolvidos nessas transações, que tiveram, como objeto de variados intercursos, a mão de obra escrava (Tabela 3).

Tabela 3 - Preços médios dos escravos em geral e segundo o sexo, dos Dias Tostes, dos Paula Lima e dos Barbosa Lage, Juiz de Fora, 1857-1886

\begin{tabular}{|c|c|c|}
\hline Sexo & Número de escravos & Preço médio (em réis) \\
\hline Homens & 51 & $1: 376 \$ 000$ \\
\hline Mulheres & 36 & $1: 043 \$ 000$ \\
\hline Homens e Mulheres & $\mathbf{8 7}$ & $\mathbf{1 : 2 3 9 \$ 0 0 0}$ \\
\hline
\end{tabular}

Fonte: Livros de Escritura Públicas, Compra e Venda de Escravos do Primeiro Ofício de Notas do AHCJF; Segundo Tabelionato de Notas de Juiz de Fora.

A média dos preços dos cativos, homens e mulheres, era de um conto duzentos e trinta e nove mil réis (1:239\$000). Os homens tiveram preços médios superiores ao das mulheres, respectivamente, um conto trezentos e setenta e seis mil réis $(1: 376 \$ 000)$ e um conto quarenta e três mil réis $(1: 043 \$ 000)$, cifras abaixo das encontradas por José Flavio Motta, em Constituição (Piracicaba-SP), nas décadas de 1860 e 1870. Segundo o pesquisador: "Houve, pois, um comportamento distinto dos preços médios reais de homens e mulheres ao longo do tempo. De fato, as escravas sofreram contínua desvalorização". ${ }^{48}$ Infelizmente, não foi possível proceder como Motta, e tentar acompanhar a variação na média dos preços dos escravos jovens/adultos, entre quinze e quarenta anos. A fonte, muitas vezes, não especifica o preço dos cativos e/ou suas idades, o que nos impediu de perceber variações nesses preços, ao longo da segunda metade do século XIX. Se tivéssemos tido esta oportunidade, talvez pudéssemos comprovar a tese de Slenes, já que os livros que investigamos, como expusemos anteriormente, abrangem o período por ele pesquisado, tal como escreveu:

\footnotetext{
${ }^{48}$ MOTTA, José Flavio. Escravos daqui, dali e de mais além: o tráfico interno de cativos em Constituição (Piracicaba), 1861-1880. Revista Brasileira de História, v. 26, n. 52, 2006, p. 41.
} 
(...) se os cativos, via de regra, eram já mais caros no Sudeste cafeeiro nos anos de 1858 e 1859 , eles passaram a ser, na maior parte dos casos, significativamente ainda mais caros em fins do decênio de 1870 e em inícios da década de 1880. Para tanto contribuíram a dinâmica diferenciada das atividades de exportação nas distintas províncias e as secas sofridas pelo Nordeste entre 1877 e $1880 .^{49}$

A informação sobre os escravos permitiu-nos perceber que a maioria era composta por mão de obra do sexo masculino, independente da origem que lhes era atribuída. Sobressaíram-se os crioulos, num total de 137 (77,4\%), logo em seguida vieram os descritos como africanos, com 40 cativos (22,6\%). A distribuição das origens de acordo com o sexo demonstra que havia: 90 crioulos e 47 crioulas, (respectivamente, $74,4 \%$ e $83,9 \%$ ). Trinta e um homens $(25,6 \%)$ e 9 mulheres $(16,1 \%)$ eram africanos. Essa estrutura não causa estranheza, por se tratar de um período no qual o tráfico de cativos, provenientes da África, se havia fechado, consequentemente, alterando as feições do escravismo, no que diz respeito à origem dos indivíduos comercializados (Tabela 4).

Tabela 4 - Sexo e origem dos escravos que fizeram parte de algum tipo de transação comercial, Juiz de Fora, 1857-1886

\begin{tabular}{|c|c|c|c|c|c|c|}
\hline Origem & Masculino & $\mathbf{\%}$ & Feminino & $\mathbf{\%}$ & Total & \% \\
\hline Crioulo & 90 & 74,4 & 47 & 83,9 & 137 & 77,4 \\
\hline Africano & 31 & 25,6 & 09 & 16,1 & 40 & 22,6 \\
\hline Total & $\mathbf{1 2 1}$ & $\mathbf{1 0 0}$ & $\mathbf{5 6}$ & $\mathbf{1 0 0}$ & $\mathbf{1 7 7}$ & $\mathbf{1 0 0}$ \\
\hline
\end{tabular}

Fonte: Livros de Escritura Públicas, Compra e Venda de Escravos do Primeiro Ofício de Notas do AHCJF; Segundo Tabelionato de Notas de Juiz de Fora.

Como foi exposto na Tabela 1, e reforçado nas Tabelas seguintes, os homens foram a maioria dos cativos comercializados naquele período. Por meio do conhecimento das províncias, onde foram matriculados, pudemos estabelecer quais suas procedências. Isso nos possibilitou também averiguar qual a nova "modalidade" de tráfico de que se valeram os Dias Tostes, os Paula Lima e os Barbosa Lage na manutenção de suas posses. Embora os escravos tenham sido alvo de vários tipos de comércio, seja por compra e venda, troca, penhor, etc., foi

${ }^{49}$ SLENES, Robert W. The demography and economics..., op. cit., 1976, p. 183. 
por meio do tráfico que passaram a fazer parte da propriedade de seus senhores. Só posteriormente foram alvo das ditas transações.

Ao analisarmos a Tabela 5, podemos averiguar que aqueles senhores envolvidos em algum tipo de comércio utilizaram principalmente o tráfico intraprovincial para a aquisição de sua mão de obra.

Foram 274 escravos oriundos da própria província mineira, uma maioria esmagadora, que perfaz a percentagem de $83,2 \%$, maior que a soma de todas as outras procedências conhecidas, cifras que se repetiram com relação ao sexo. Todos os homens e mulheres com procedência conhecida (respectivamente, $79,9 \%$ e $89,1 \%$ ) eram oriundos de Minas Gerais. Os cativos provenientes do tráfico interprovincial perfizeram um total de 49 (15,0\%). Dentre eles, com exceção dos provenientes de Pernambuco e Goiás, as outras províncias mantiveram a tendência de contribuir com mais homens do que mulheres. Havia ainda os de procedência africana. Eram 6, 5 homens e 1 mulher, que, a priori, provieram do tráfico intercontinental e, mais uma vez, foram alvo de algum tipo de transação comercial $(1,8 \%)$. Essa supremacia masculina, uma vez mais, parece demonstrar que a localidade ainda vivenciava um período de desenvolvimento baseado na plantation do café, que demandava trabalhadores escravos, sobretudo do sexo masculino. Como bem lembrou Motta, esses escravos "constituir-se-iam nas 'peças' preferidas no comércio de cativos, sejam os importados da África, sejam os oriundos do tráfico interno". ${ }^{50}$

${ }^{50}$ MOTTA, José Flavio, op. cit., 1999, p. 299. 
Jonis FREIRE. Crescimento da população cativa em uma economia agroexportadora.

Tabela 5 - Sexo dos cativos comprados e vendidos pelos Dias Tostes, pelos Paula Lima e pelos Barbosa Lage, de acordo com a procedência e a província onde foram matriculados, Juiz de Fora, 1857-1886

\begin{tabular}{|c|c|c|c|c|c|c|c|}
\hline \multicolumn{2}{|c|}{\begin{tabular}{l|} 
Província \\
/procedência
\end{tabular}} & Masculino & $\%$ & Feminino & $\%$ & Total & $\%$ \\
\hline \multirow{3}{*}{ Sudeste } & Minas Gerais & 167 & 79,9 & 107 & 89,1 & 274 & 83,2 \\
\hline & Rio de Janeiro & 07 & 3,3 & 01 & 0,9 & 08 & 2,4 \\
\hline & Espírito Santo & 03 & 1,5 & - & - & 03 & 1,0 \\
\hline \multirow{8}{*}{ Nordeste } & Ceará & 10 & 4,8 & 02 & 1,6 & 12 & 3,6 \\
\hline & Bahia & 10 & 4,8 & 02 & 1,6 & 12 & 3,6 \\
\hline & Alagoas & 03 & 1,5 & 01 & 0,9 & 04 & 1,3 \\
\hline & Pernambuco & 01 & 0,5 & 03 & 2,5 & 04 & 1,3 \\
\hline & Piauí & - & - & 01 & 0,9 & 01 & 0,3 \\
\hline & Paraíba do Norte & 01 & 0,5 & - & - & 01 & 0,3 \\
\hline & Paraíba & 01 & 0,5 & - & - & 01 & 0,3 \\
\hline & Maranhão & 01 & 0,5 & - & - & 01 & 0,3 \\
\hline $\begin{array}{l}\text { Centro- } \\
\text { Oeste }\end{array}$ & Goiás & - & - & 02 & 1,6 & 02 & 0,6 \\
\hline \multirow{4}{*}{ África } & Cabinda & 02 & 0,9 & - & - & 02 & 0,6 \\
\hline & Congo & 02 & 0,9 & - & - & 02 & 0,6 \\
\hline & Rebolo & 01 & 0,5 & - & - & 01 & 0,3 \\
\hline & Benguela & - & - & 01 & 0,9 & 01 & 0,3 \\
\hline \multicolumn{2}{|c|}{ Total } & 209 & 100 & 120 & 100 & 329 & 100 \\
\hline
\end{tabular}

Fonte: Livros de Escritura Públicas, Compra e Venda de Escravos do Primeiro Ofício de Notas do AHCJF; Segundo Tabelionato de Notas de Juiz de Fora.

Os cativos, vindos de outras partes do Império, variaram entre no mínimo 1 e no máximo 12. Pois bem, se os agruparmos por regiões, excetuando-se a Província de Minas Gerais, percebemos que a maioria era proveniente do Nordeste brasileiro, 12 do Ceará, o mesmo número da Bahia, de Alagoas e Pernambuco, cada um com 4, enquanto as Províncias do Piauí, da Paraíba do Norte, da Paraíba e do Maranhão participaram com 1 escravo cada, totalizando, então, 36. O segundo maior contingente foi proveniente da região Sudeste: do Rio de Janeiro e do Espírito Santo, respectivamente, 8 e 3. Por fim, temos 2 indivíduos provenientes de Goiás, que se localiza no Centro-Oeste. No que diz respeito à aquisição de cativos, os oriundos da região Nordeste representaram 11\%. Muito provavelmente, houve uma conjunção de fatores, como sugere Slenes. O primeiro teria sido a própria dinâmica das regiões exportadoras de café do Centro-Sul, que continuavam a demandar mão de obra em suas lavouras, e que, agora, só poderia ser adquirida por meio do tráfico nacional. O segundo teria sido a crise enfrentada 
pelos proprietários de cativos do Nordeste brasileiro, principalmente com a seca que assolou aquela região na segunda metade do século XIX..$^{51}$

Cláudio Heleno Machado, em seu estudo sobre a mesma localidade, valendo-se da análise de farta documentação, afirma que

O tráfico interprovincial (...) teve tanta significação que em Juiz de Fora encontravam-se escravos procedentes, praticamente, de todo o território nacional, pelo menos onde havia mão de obra cativa que pudesse ser transferida. (...) Destacam-se nas transferências para Juiz de Fora, nesta modalidade do tráfico interno, as regiões do Nordeste e o próprio Centro-Sul: 61,57 e 33,21\%, respectivamente. Embora com parcelas ínfimas, as regiões Oeste e Sul do país também contribuíram com transferências de escravos para Juiz de Fora: 3,36 e $1,86 \%$ do total apurado por este estudo, também respectivamente..$^{52}$

A análise mais detida da província/procedência permite observar quais as localidades (cidade, vila, distrito, etc.) em que foram matriculados os cativos. Conseguimos conhecer esse aspecto para 321 deles $(51,2 \%)$, que fizeram parte das transações comerciais envolvendo os Dias Tostes, os Paula Lima e os Barbosa Lage, entre 1857 e 1886.

Dos 49 escravos provenientes do tráfico interprovincial, foi possível saber o local de matrícula de 46. Do Nordeste vieram 32, a maioria proveniente do Ceará. Foram 12 os negociados dessa província, 3 matriculados em Maranguape e outros 2 em Ipui; para outros 4 não foi possível saber o local da matrícula. ${ }^{53}$ Existiu ainda 1 cativo descrito apenas como matriculado no Ceará. Os 2 restantes se distribuíram igualmente entre Lavras e Sobral. O segundo maior contingente negociado por aquelas famílias era proveniente da Bahia, totalizando 9 indivíduos: Santo Antonio da Barra forneceu 3, Campo Largo 2, e Maragogipe, Remanso,

\footnotetext{
${ }^{51}$ Sobre os problemas enfrentados pelo Nordeste e o aumento do fluxo de cativos daquela região com destino às de produção cafeeira, conferir, entre outros, CONRAD, Robert. Os últimos anos..., op. cit. Segundo Peter Eisenberg, "O tráfico interprovincial chegou ao auge na década de 1870 em virtude das severas secas nordestinas que forçaram a liquidação dos ativos fixos, como os escravos. O total de escravos embarcados para o sul, após 1876, foi tão elevado que as províncias compradoras - Rio de Janeiro, São Paulo e Minas Gerais - impuseram elevados tributos à importação de escravos, em 1880 e 1881. (...) Os tributos acabaram com o tráfico interprovincial de escravos". EISENBERG, Peter. Modernização sem mudança: a indústria açucareira em Pernambuco, 1840-1910. Rio de Janeiro; Campinas: Paz e Terra; Universidade Estadual de Campinas, 1977, p. 175-177.

${ }^{52}$ MACHADO, Cláudio Heleno. Tráfico interno de escravos estabelecidos na direção de um município da região cafeeira de Minas Gerais: Juiz de Fora, na Zona da Mata (segunda metade do século XIX). Monografia do Curso de especialização em História do Brasil. Universidade Federal de Juiz de Fora, 1998, p. 66.

${ }^{53}$ Para 2 desses 4 cativos só conseguimos saber parte do nome do local (Joa?).
} 
Carinhanha e Feira de Santana 1 escravo cada; para os outros 3 não conseguimos obter essa informação. A Província de Pernambuco forneceu 2 escravos, matriculados no Recife, 1 em Limoeiro e outro em Oiricury. Quatro outras províncias nordestinas negociaram escravos em Juiz de Fora. Alagoas forneceu 4 cativos, divididos entre Afonso, Maceió, Paulo Affonso e Santo Antonio. O Maranhão contou com 1 indivíduo matriculado na alfândega dessa província. O Piauí contou com o mesmo número de escravos, matriculados em Valença, assim como o matriculado em Souza, na Parahyba do Norte.

O Sudeste - ou o Centro-Sul - participou com 11 escravos, distribuídos entre a Corte e as Províncias do Rio de Janeiro e do Espírito Santo. A primeira teve 7 matriculados. A segunda negociou 1 escravo oriundo de Campos e a terceira outros 3, vindos de Serra. Por fim, encontramos 2 matriculados em Catalão, Goiás. Existiu ainda mais 1, cuja província ou local de matrícula esta ininteligível.

Robert Slenes, em estudo sobre o tráfico interno de escravos, detectou que o número de traficados para o centro-sul do Brasil, entre meados dos anos de 1850 e 1881, em transferências inter-regionais, esteve por volta de 222.500 indivíduos, uma média de 7.200 por ano, para todo aquele período. ${ }^{54}$

Como já pudemos observar anteriormente, a grande maioria dos cativos que foi alvo de algum tipo de transação comercial, segundo as fontes, estava matriculada na província mineira e, nesse aspecto, algumas considerações são interessantes (Tabela 6).

\footnotetext{
${ }^{54}$ SLENES, Robert. The Brazilian Internal Slave Trade..., op. cit. p. 331. Richard Graham percebeu que o tráfico interno de escravos e os escravos tiveram importante papel no fim da escravidão. GRAHAM, Richard. Another Middle Passage? The Internal Slave Trade in Brazil. In: JOHNSON, Walter (Org.). Domestic Passages..., op. cit.
} 
Jonis FREIRE. Crescimento da população cativa em uma economia agroexportadora.

Tabela 6 - Localidade da matrícula dos cativos dos Dias Tostes, dos Paula Lima e dos Barbosa Lage, oriundos do tráfico intraprovincial e local, Juiz de Fora, 1857-1886

\begin{tabular}{|c|c|c|}
\hline Tipo de tráfico & Número de cativos negociados & $\%$ \\
\hline $\begin{array}{l}\text { Intraprovincial/Local* } \\
\text { Regiões/Municípios }\end{array}$ & & \\
\hline \multicolumn{3}{|c|}{ Zona da Mata } \\
\hline Mar de Hespanha & 06 & 2,2 \\
\hline Ponte Nova & 04 & 1,5 \\
\hline Juiz de Fora & 213 & 77,8 \\
\hline Subtotal & 223 & 81,5 \\
\hline \multicolumn{3}{|c|}{ Jequitinhonha Mucuri-Doce } \\
\hline Grão Mogol & 06 & 2,2 \\
\hline Diamantina & 05 & 1,9 \\
\hline Arrasuahy & 04 & 1,5 \\
\hline Minas Novas & 02 & 0,7 \\
\hline Subtotal & 17 & 6,3 \\
\hline \multicolumn{3}{|c|}{ Metalúrgica Mantiqueira } \\
\hline Abaeté & 03 & 1.1 \\
\hline Queluz & 03 & 1,1 \\
\hline Arassandy & 01 & 0,3 \\
\hline Barbacena & 02 & 0,8 \\
\hline Sete Lagoas & 03 & 1,1 \\
\hline Sabará & 02 & 0,8 \\
\hline Santa Luzia & 01 & 0,3 \\
\hline Subtotal & 15 & 5,5 \\
\hline \multicolumn{3}{|c|}{ Oeste } \\
\hline Pará & 10 & 3,6 \\
\hline Tamanduá & 01 & 0,3 \\
\hline Subtotal & 11 & 3,9 \\
\hline \multicolumn{3}{|c|}{ Alto Paranaíba } \\
\hline Araxá & 05 & 1,9 \\
\hline Subtotal & 05 & 1,9 \\
\hline \multicolumn{3}{|c|}{ São Francisco Montes-Claros } \\
\hline Januária & 01 & 0,3 \\
\hline Montes Claros da Formiga & 01 & 0,3 \\
\hline Subtotal & 02 & 0,6 \\
\hline \multicolumn{3}{|c|}{ Sul } \\
\hline Pouso Alegre & 01 & 0,3 \\
\hline Subtotal & 01 & 0,3 \\
\hline Total de escravos negociados & 274 & $100 \%$ \\
\hline
\end{tabular}

Fonte: Livros de Escritura Públicas, Compra e Venda de Escravos do Primeiro Ofício de Notas do AHCJF; Segundo Tabelionato de Notas de Juiz de Fora.

*O tráfico local é aquele que ocorre dentro dos limites do município de Juiz de Fora. Optamos por deixá-lo junto à região, Zona da Mata. 
Por meio da Tabela acima, podemos perceber que, dos 274 cativos provenientes da própria província mineira, cuja procedência foi possível conhecer, $61(22,3 \%)$ eram oriundos do tráfico intraprovincial (entre Juiz de Fora e outros municípios mineiros), os outros $213(77,7 \%)$, do tráfico local interno, dentro dos limites do município de Juiz de Fora. O tráfico intraprovincial, sobretudo aquele oriundo do comércio local de escravos provenientes da própria Zona da Mata e em específico de Juiz de Fora, foi o responsável pela esmagadora maioria dos escravos negociados. ${ }^{55}$

Fica patente a preferência dos envolvidos naquelas transações, em primeiro lugar, por escravos oriundos do próprio município e, em seguida, por aqueles vindos das demais regiões mineiras. Essa mesma constatação foi feita por Cláudio Heleno Machado. O pesquisador concluiu que os escravos negociados pelos senhores, na mesma localidade, eram oriundos do tráfico local, intraprovincial e, por último, do interprovincial. ${ }^{56}$

Ainda de acordo com a Tabela 6 e tomando por base os modelos expostos por Roberto Martins e Douglas Libby - em que eles estabeleceram uma divisão dos distritos mineiros de acordo com a distribuição da propriedade de escravos -, é possível perceber que localidades vinham perdendo cativos para a Zona da Mata Mineira e, em específico, para o município de Juiz de Fora. ${ }^{57}$ Essa mesma tendência foi percebida por Garavazo, em seu já citado estudo sobre Batatais. Naquela região, verificou-se o caráter local do comércio de escravos, sobretudo pelo conhecimento do lugar de moradia de compradores, vendedores e também dos procuradores, bem como por meio do conhecimento da naturalidade dos cativos e dos ingênuos transacionados.

Verificou-se que $88,4 \%$ das pessoas que compraram cativos e ingênuos e $80,9 \%$ daquelas que venderam residiam em Batatais (na cidade ou no termo). Em apenas quarenta transações ( $12,5 \%$ do total) o vendedor foi representado por um procurador, número que se igualou

\footnotetext{
${ }^{55}$ Sobre a importância dos tráficos local e intraprovincial de escravos conferir os importantes trabalhos de: MOTTA, José Flavio. Escravos daqui, dali e de mais além,..., op.cit. MARTINS, Ismênia de Lima. Problemas da extinção do tráfico africano na província do Rio de Janeiro. Uma tentativa de análise das dificuldades de reposição de mão de obra na grande lavoura fluminense. Tese de Doutorado. FFLCH, USP, 1973.

${ }^{56}$ MACHADO, Cláudio Heleno. Tráfico interno de escravos..., op. cit.

${ }^{57}$ LIBBY, Douglas Cole. Transformação e trabalho..., op. cit., p. 33; MARTINS, Roberto Borges. Minas Gerais, século XIX:..., op. cit.
} 
a tão somente trinta e dois $(10,0 \%)$ no caso dos compradores. E, ainda mais, verificou-se que sessenta e um, destes setenta e dois procuradores, moravam em Batatais. ${ }^{58}$

Os escravos negociados dentro dos limites mineiros eram de quase todas as regiões, com exceção do Triângulo e de Paracatu. Muitos deles vinham de áreas onde não havia concentração de algum produto que pudesse ser responsável pela manutenção ou, até mesmo, pela ampliação de suas posses de escravos, regiões que, em sua maioria, se caracterizavam pela pequena propriedade, mais sujeita às oscilações do mercado. Essa parece ser a explicação para o número de cativos das regiões de Jequitinhona e Mucuri-Doce (6,3\%). O mesmo raciocínio vale para São Francisco - Montes Claros contribuiu com 0,6\%. ${ }^{59}$ As regiões Metalúrgica Mantiqueira (5,5\%), Oeste $(3,9 \%)$, Alto Paranaíba $(1,9 \%)$ e Sul $(0,3 \%)$ devem ter contribuído para o incremento da mão de obra escrava, também pelos mesmos motivos (Mapa 1).

Num primeiro momento, o número de cativos negociado com a Zona da Mata causa estranheza, já que essa seria a região possuidora do maior contingente deles, devido à alta concentração das posses e também porque, àquela época, tinha um produto importante que demandava força de trabalho, portanto, estaria sendo recebedora e não distribuidora de escravos. A Tabela 6 nos permite conhecer as duas localidades da Mata Mineira que negociaram cativos com aquelas famílias que lá habitavam. Cabe, neste momento, ressaltar que Mar de Hespanha e Ponte Nova eram muito diferentes, do ponto de vista econômico e demográfico.

Mar de Hespanha, localizada na Zona da Mata Sul, foi um importante centro cafeicultor, durante todo o período, e seria de se esperar que estivesse ganhando e não perdendo cativos. Em uma análise mais detida a respeito dos tipos de negócios que geraram aquela transferência, podemos averiguar que, dos 6 indivíduos negociados, apenas 1 o foi por meio de compra e venda, os outros 5 eram oriundos de uma escritura pública de dívida, obrigação e hipoteca, ou seja, quase a totalidade deles só foi comercializada porque deve ter havido, por parte de seu proprietário, quem sabe, um mau gerenciamento dos negócios. Dessa forma, a transferência se deu por motivos outros que não a incapacidade da região para manter seus cativos. ${ }^{60}$ Já Ponte Nova se enquadraria no que chamamos de Zona

${ }^{58}$ GARAVAZO, Juliana. Riqueza e escravidão..., op. cit., p. 238.

${ }^{59}$ Sobre algumas características do norte mineiro àquela época, conferir a dissertação de BOTELHO, Tarcísio Rodrigues. Famílias e escravarias:..., op. cit.

${ }^{60}$ Segundo Cláudio Heleno Machado, os municípios da Mata foram muito menos afetados por transferências de cativos para Juiz de Fora, pois a região concentrava os principais municípios 
da Mata Norte, compunha a parte mais pobre daquela região, com características completamente diferentes das outras duas. Pensamos que esses contrastes, dentro da Zona da Mata, explicam esse perfil dos escravos negociados por tal área.

O que pudemos vislumbrar, até aqui, é que as famílias dos Dias Tostes, dos Paula Lima e dos Barbosa Lage se valeram de processos diferenciados em relação à manutenção e/ou ampliação de suas posses de escravos, mesmo porque atravessaram diferentes conjunturas, com peculiaridades distintas, o que, certamente, contribuiu para a diversidade de suas estratégias. As duas primeiras fizeram uso de processos de compra de cativos no comércio interno, embora os Dias Tostes tenham participado muito mais do tráfico internacional. Entretanto, tudo indica que essa não foi a atitude tomada pelo Capitão Manoel Ignácio Barbosa Lage, que parece ter-se utilizado da reprodução natural para incrementar seu contingente cativo.

Talvez tenha contribuído para as especificidades de cada dono de terras o instante de formação das suas propriedades, ou seja, o momento anterior ou posterior ao fim do tráfico, que levou a um rearranjo no que diz respeito à aquisição e à relação com a mão de obra cativa. De acordo com Isabel Reis, em estudo sobre a família negra na Bahia, entre os anos de 1850 e 1888,

Não há divergências sobre o fato de que depois da supressão do comércio transatlântico de escravizados, os proprietários brasileiros ficaram mais atentos no sentido de preservar os cativos e seus descendentes. Há uma propensão a se acreditar que principalmente a partir da lei de 1850 , se verificou até mesmo um maior incentivo aos casamentos e à procriação entre eles. ${ }^{61}$

Cabe ressaltar que o aumento do contingente cativo desses senhores, por meio das várias modalidades de tráfico, bem como da reprodução natural, se fez presente em suas propriedades. O que acima concluímos diz respeito à principal prática utilizada por eles e, de maneira alguma, ignoram-se as possibilidades da ocorrência daqueles dois processos (reprodução natural e tráfico), que poderiam possibilitar a manutenção e/ou a ampliação do número de escravos.

Conclui-se que as duas opções para o aumento do número de cativos parecem não ter sido excludentes na referida localidade, mas sim complementares. A opção por uma ou outra dependeu, sobremaneira, do período de formação das posses, da maior ou menor proximidade do tráfico transatlântico e também do raciocínio

cafeeiros da província, sendo responsáveis também por importantes concentrações de mão de obra escrava. MACHADO, Cláudio Heleno. Tráfico interno de escravos..., op. cit.

${ }^{61}$ REIS, Isabel Cristina Ferreira dos. A família negra no tempo da escravidão: Bahia, 1850-1888. Tese de Doutorado, História, Universidade Estadual de Campinas, 2007, p. 43. 
econômico empreendido pelos senhores na busca pelo melhor "modelo" para a manutenção e/ou a ampliação de suas propriedades.

De qualquer maneira, predominou muito a importação de escravos como modo de reprodução/ampliação da mão de obra. O Capitão Lage foi um exemplo entre os grandes possuidores de escravos, que parece ter utilizado a reprodução natural, e, mesmo entre eles, é caso único. Entre pequenos e médios proprietários - em que parecia haver menos estabilidade da comunidade escrava - deveria ser maior ainda a importância da importação de cativos.

Mapa 1 - Porcentagem dos cativos pertencentes aos Dias Tostes, aos Paula Lima e aos Barbosa Lage, oriundos do tráfico intraprovincial e local, segundo a região, Juiz de Fora, 1857-1886

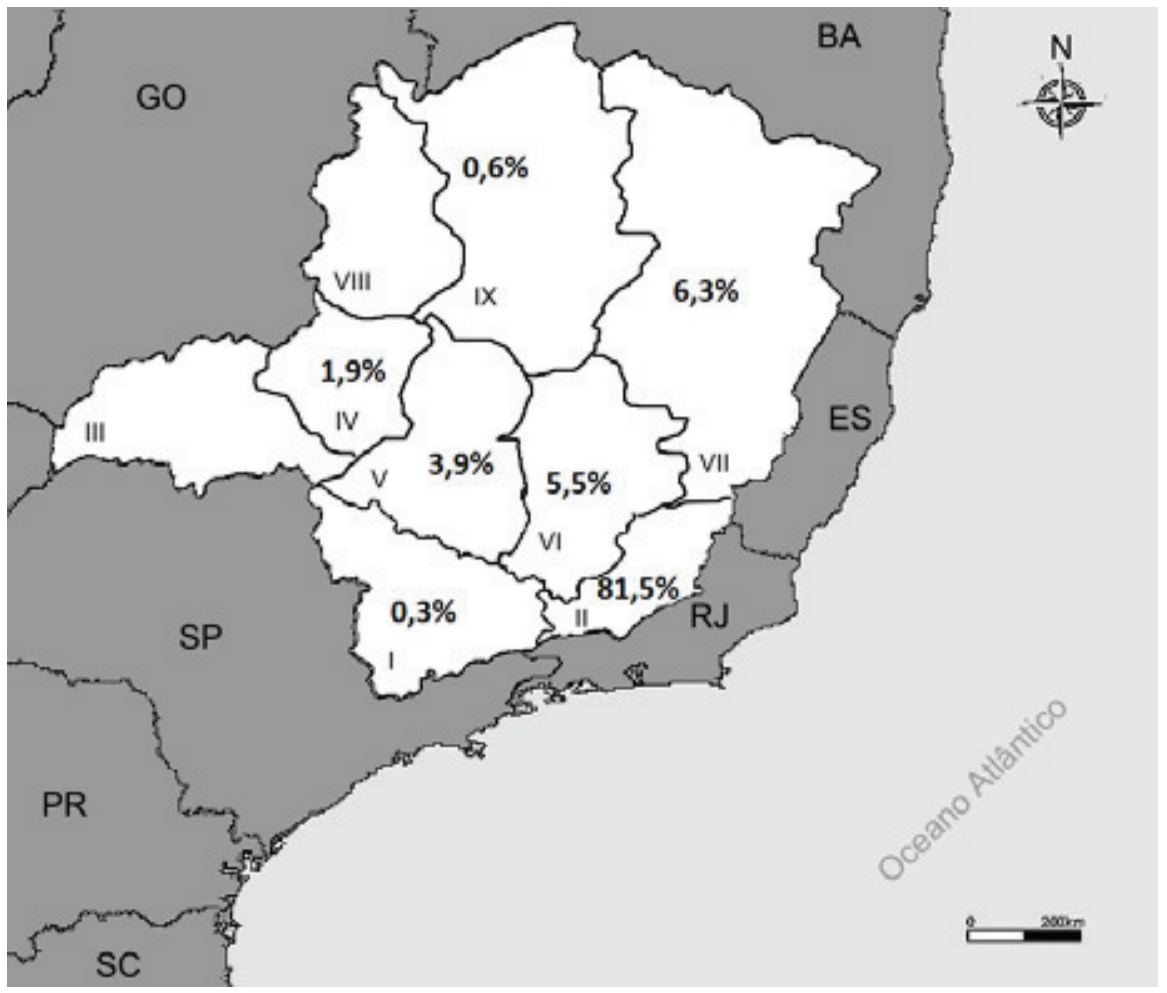

Fonte: Elaborado pelo Prof. Dr. Luiz Fernando Saraiva (UFRB) a partir de LIBBY, 1988. I Sul; II Mata; III Triângulo; IV Alto Parnaíba; V Oeste; VI Metalúrgica-Mantiqueira; VII Jequitinhonha-Mucuri-Doce; VIII Paracatu; IX São Francisco-Montes Claros. 
Jonis FREIRE. Crescimento da população cativa em uma economia agroexportadora.

\section{Obra de Referência}

SILVA, Antonio de Moraes. Dicionário da Língua Portuguesa. Lisboa: Typ. de Antonio Jose da Rocha, $6^{\mathrm{a}}$ ed., 1858.

\section{Referências Bibliográficas}

ANDRADE, Rômulo Garcia de. Limites impostos pela escravidão à comunidade escrava e seus vínculos de parentesco: Zona da Mata de Minas Gerais, século XIX. Tese de Doutorado, História, USP, 1995.

BACELLAR, Carlos de Almeida; SCOTT, Ana Silvia Volpi. Sobreviver na senzala: estudo da composição e continuidade das grandes escravarias paulistas, 17981818. In: NADALIN, Sérgio Odilon; et. alii (Coords.). História e população: estudos sobre a América Latina. São Paulo: Fundação Sistema Estadual de Análise de Dados, 1990.

BERGAD, Laird W. Escravidão e história econômica: demografia de Minas Gerais, 1720-1888. Bauru: EDUSC, 2004.

BOTELHO, Tarcísio Rodrigues. Famílias e escravarias: demografia e família escrava no norte de Minas Gerais no século XIX. Dissertação de Mestrado, FFLCH, USP, 1994.

. Famílias e escravarias: demografia e família escrava no norte de Minas Gerais no século XIX. População e família, v. 1, n. 1, jan-jun 1988.

CANO, Wilson; LUNA, Francisco Vidal. A reprodução natural de escravos em Minas Gerais (século XIX): uma hipótese. Cadernos IFCH-UNICAMP. v. 10, out 1983.

CARRARA, Angelo Alves. A Zona da Mata de Minas Gerais: diversidade econômica e continuísmo (1839-1909). Dissertação de Mestrado, História, Universidade Federal Fluminense, 1993.

CONRAD, Robert. Os últimos anos da escravatura no Brasil 1850-1888. Rio de Janeiro: Civilização Brasileira, 1978.

COSTA, Emilia Viotti da. Da senzala à Colônia. São Paulo: DIFEL, 1966.

EISENBERG, Peter. Modernização sem mudança: a indústria açucareira em Pernambuco, 1840-1910. Rio de Janeiro; Campinas: Paz e Terra; Universidade Estadual de Campinas, 1977.

ELTIS, David. The volume and structure of the transatlantic slave trade: a reassessment. William and Mary Quaterly, 3d Series, v. 58, n. I, jan 2001.

FLORENTINO, Manolo. Em costas negras: uma história do tráfico de escravos entre a África e o Rio de Janeiro, século XVIII e XIX. São Paulo: Companhia das Letras, 1997.

FRAGOSO, João Luis; FERREIRA, Roberto Guedes. Alegrias e Artimanhas de uma fonte seriada, despacho de escravos e passaportes da Intendência de Polícia da Corte, 1819-1833. Seminário de História Quantitativa e Serial no Brasil: um balanço. Ouro Preto: ANPUH-MG, 2001. 
Jonis FREIRE. Crescimento da população cativa em uma economia agroexportadora.

FREIRE, Jonis. Escravidão e família escrava na Zona da Mata Mineira oitocentista. Tese de Doutorado, História, Universidade Estadual de Campinas, 2009.

FURTADO, Celso. Formação econômica do Brasil. São Paulo: Nacional, $7^{\mathrm{a}}$ ed., 1969.

GARAVAZO, Juliana. Riqueza e escravidão no Nordeste Paulista: Batatais, 18511887. Dissertação de Mestrado, História Econômica, FFLCH, USP, 2006.

GRAHAM, Richard. Another Middle Passage? The Internal Slave Trade in Brazil. In: JOHNSON, Walter (Org.). Domestic Passages: Internal Slave Trades in the Americas, 1808-1888. New Haven: Yale University Press, 2005.

GUIMARÃES, Elione Silva. Múltiplos viveres de afrodescendentes na escravidão e no pós-emancipação: família, trabalho, terra e conflito (Juiz de Fora-MG, 1828-1928). São Paulo; Juiz de Fora: Annablume; Funalfa Edições, 2006.

GUTIÉRREZ, Horacio. Demografia escrava numa economia não-exportadora: Paraná, 1800-1830. Estudos Econômicos, v. 17, n. 2, maio-ago 1987.

KLEIN, Herbert S. A demografia do tráfico atlântico de escravos para o Brasil. Estudos Econômicos, v. 17, n. 2, maio-ago 1987.

LACERDA, Antonio Henrique Duarte. Os padrões de alforrias em um municipio cafeeiro em expansão: Juiz de Fora, Zona da Mata de Minas Gerais, 1844-1888. São Paulo: Fapeb; Annablume, 2006.

LIBBY, Douglas Cole. Minas na mira dos Brasilianistas: reflexões sobre os trabalhos de Higgins e Bergad. In: BOTELHO, Tarcísio Rodrigues (Org.). História Quantitativa e Serial: um balanço. Belo Horizonte: ANPUH-MG, 2001.

. Transformação e trabalho em uma economia escravista: Minas Gerais no século XIX. São Paulo: Brasiliense, 1988.

. Resenha. American Historical Review, v. 107, n. 1, 2002, p. 258-9.

LENHARO, Alcir. As tropas da moderação. São Paulo: Símbolo, 1979.

LUNA, Francisco Vidal; CANO, Wilson. Economia escravista em Minas Gerais. Cadernos IFCH/UNICAMP, v. 10, out 1983.

; KLEIN, Herbert S. Evolução da Sociedade e Economia Escravistas de São Paulo, de 1750 a 1850. São Paulo: EDUSP, 2005.

MACHADO, Cláudio Heleno. Tráfico interno de escravos estabelecidos na direção de um município da região cafeeira de Minas Gerais: Juiz de Fora, na Zona da Mata (segunda metade do século XIX). Monografia do Curso de especialização em História do Brasil, Universidade Federal de Juiz de Fora, 1998.

MARTINS, Ismênia de Lima. Problemas da extinção do tráfico africano na província do Rio de Janeiro. Uma tentativa de análise das dificuldades de reposição de mão de obra na grande lavoura fluminense. Tese de Doutorado, FFLCH, USP, 1973.

MARTINS, Roberto Borges. Minas Gerais, século XIX: tráfico e apego à escravidão numa economia não-exportadora. Estudos Econômicos, v. 13, n. 1, jan-abr 1983, p. 181-209. 
Growing in silence: the slave economic of nineteenth century Minas Gerais (Brazil). Tese de Doutorado, University Vanderbilt, 1980.

A economia escravista de Minas Gerais no século XIX. Belo Horizonte: Cedeplar, 1980.

; MARTINS, Maria do Carmo Salazar. RBEP, v. 58, jan 1984, p. 105-120.

Minas e o tráfico de escravos no século XIX, outra vez. In: SZMREC-

SÁNYI, Tamás; LAPA, José Roberto do Amaral. História econômica da independência ao império. São Paulo: HUCITEC, 1996.

MARTINS FILHO, Amílcar; MARTINS, Roberto Borges. Slavery in a non-export economy: nineteenth century Minas Gerais revisited. Hispanic American Historical Review, v. 63, n. 3, 1983, p. 537-568.

MATTOS DE CASTRO, Hebe Maria. Ao sul da história. São Paulo: Brasiliense, 1987.

Laços de família e direitos no final da escravidão. In: ALENCASTRO, Luiz Felipe de. História da Vida Privada no Brasil: Império. São Paulo: Companhia da Letras, $7^{\mathrm{a}}$ reimp., 2004.

MATTOSO, Kátia Queiroz; KLEIN, Herbert; ENGERMAN, Stanley L. Notas sobre as tendências e padrões dos preços de alforria na Bahia, 1819-1888. In: REIS, João José (Org.). Escravidão e invenção da liberdade. Estudos sobre o negro no Brasil. São Paulo: Brasiliense, 1988.

MOTTA, José Flavio. Jovens \& Coisas: transações envolvendo escravos de 9 a 17 anos de idade (Província de São Paulo, 1861-1887). In: SOARES, Marcio de Souza; FERREIRA, Roberto G.; FARIA, Sheila. S. C. I Colóquio Nacional Ordem e Ruptura em Debate: escravidão e alforria. UFF, 2011.

; MARCONDES, Renato Leite. O comércio de escravos no vale do Paraíba paulista: Guaratinguetá e Silveiras na década de 1870. Estudos Econômicos. v. 30, n. 2,2000 , p. $267-299$.

Escravos daqui, dali e de mais além: o tráfico interno de cativos em Constituição (Piracicaba), 1861-1880. Revista Brasileira de História. São Paulo, v. 26, n. $52,2006$.

Escravos daqui, dali e de mais além: o tráfico interno de cativos na expansão cafeeira paulista (Areias, Guaratinguetá, Constituição/Piracicaba e Casa Branca, 1861-1887). Tese de Livre Docência, FEA, USP, 2010.

NEIBOER, H. J. Slavery as an industrial system. Nova York: Burt Franklin, 1971.

NOGUERÓL, Luiz Paulo Ferreira de. Economia escravista e preços de escravos em Minas Gerais: o caso de Sabará entre 1850 e 1887. Dissertação de Mestrado, Economia, CEDEPLAR, UFMG, 1997.

PAIVA, Clotilde A.; LIBBY, Douglas C. Caminhos alternativos: escravidão e reprodução em Minas Gerais no século XIX. Estudos Econômicos, v. 25, n. 2, maio-ago 1995, p. 203-233. 
Jonis FREIRE. Crescimento da população cativa em uma economia agroexportadora.

; MARTINS, Maria do Carmo Salazar. Revisão crítica do recenseamento de 1872. Anais do Segundo Seminário sobre Economia Mineira. Belo Horizonte: CEDEPLAR; FACE; UFMG, 1983.

PAIVA, Eduardo França. Escravidão e universo cultural na colônia: Minas Gerais, 1716-1789. Belo Horizonte: UFMG, 2001.

PINHEIRO, Fabio Wilson Amaral. O tráfico atlântico de escravos na formação dos plantéis mineiros, Zona da Mata (c.1809 - c.1830). Dissertação de Mestrado, História, Universidade Federal do Rio de Janeiro, 2007.

REIS, Isabel Cristina Ferreira dos. A família negra no tempo da escravidão: Bahia, 1850-1888. Tese de Doutorado, Universidade Estadual de Campinas, 2007.

RODRIGUES, Jaime. O infame comércio: propostas e experiências no final do tráfico de africanos para o Brasil (1800-1850). Campinas: Unicamp; CECULT, 2000.

SALLES, Ricardo. E o Vale era o escravo. Vassouras, século XIX. Senhores e escravos no coração do Império. Rio de Janeiro: Civilização Brasileira, 2008.

SANTOS, Jonas Rafael dos. Senhores e escravos: a estrutura da posse de escravos em Mogi das Cruzes no início do século XIX. Estudos de História, v. 9, n. 2, 2002.

SLENES, Robert. Os múltiplos de porcos e diamantes: a economia escrava de Minas Gerais no século XIX. Estudos Econômicos, v. 18, n. 3, 1988.

. The Brazilian Internal Slave Trade, 1850-1888: regional economies, slave experience and the politics of a peculiar market. In: JOHNSON, Walter (Org.). Domestic Passages: Internal Slave Trades in the Americas, 1808-1888. New Haven: Yale University Press, 2005.

. The demography and economics of brazilian slavery: 1850-1888. Tese de Doutorado, Stanford University, 1976.

TEIXEIRA, Heloisa Maria. Reprodução e famílias escravas de Mariana (1850-1888). Dissertação de Mestrado, História Econômica, Universidade de São Paulo, 2001.

WINCH, Donald. Classical political economy and the colonies. Cambridge: Harvard University Press, 1965.

Recebido: 09/06/2011 - Aprovado: 09/03/2012 